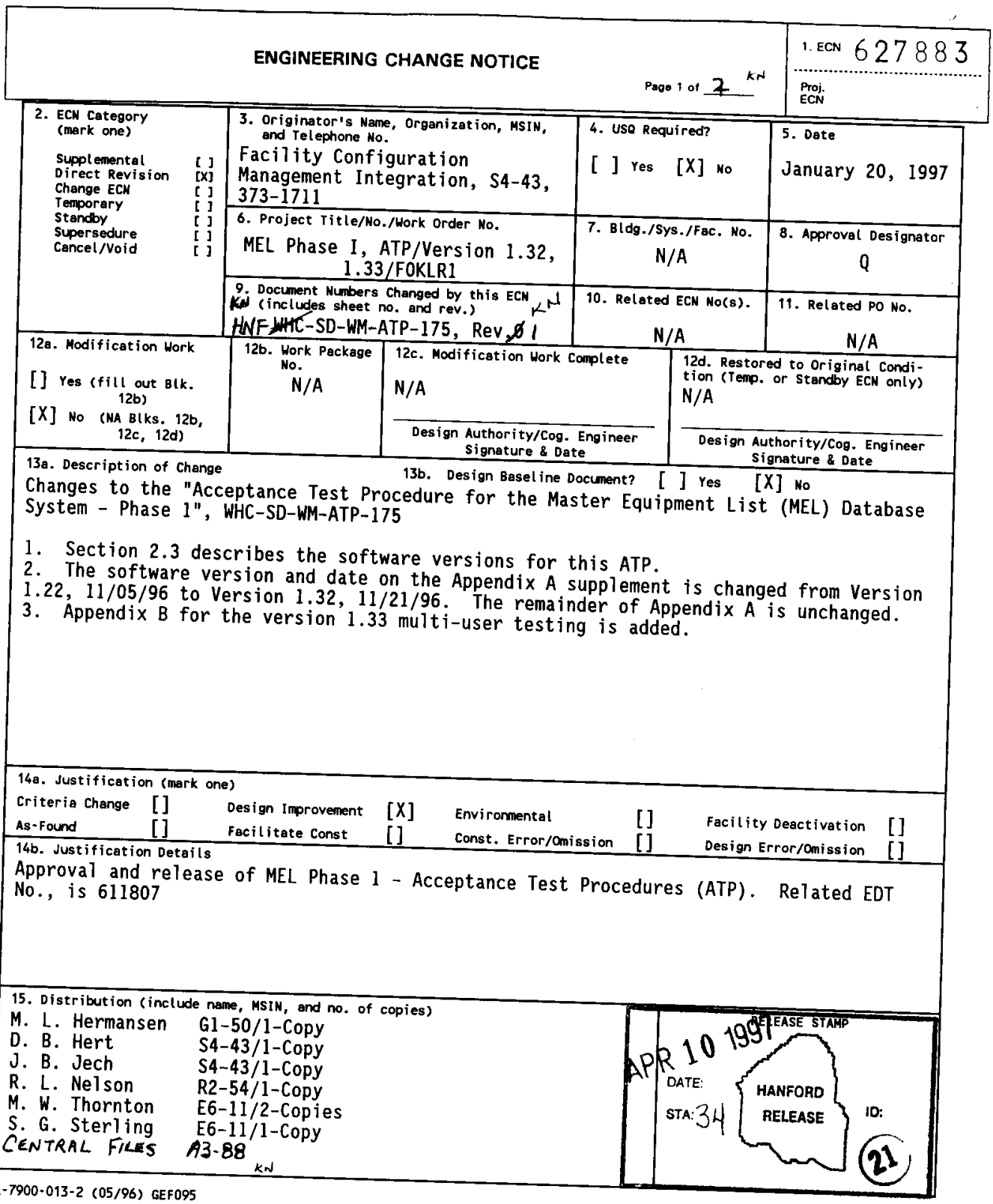




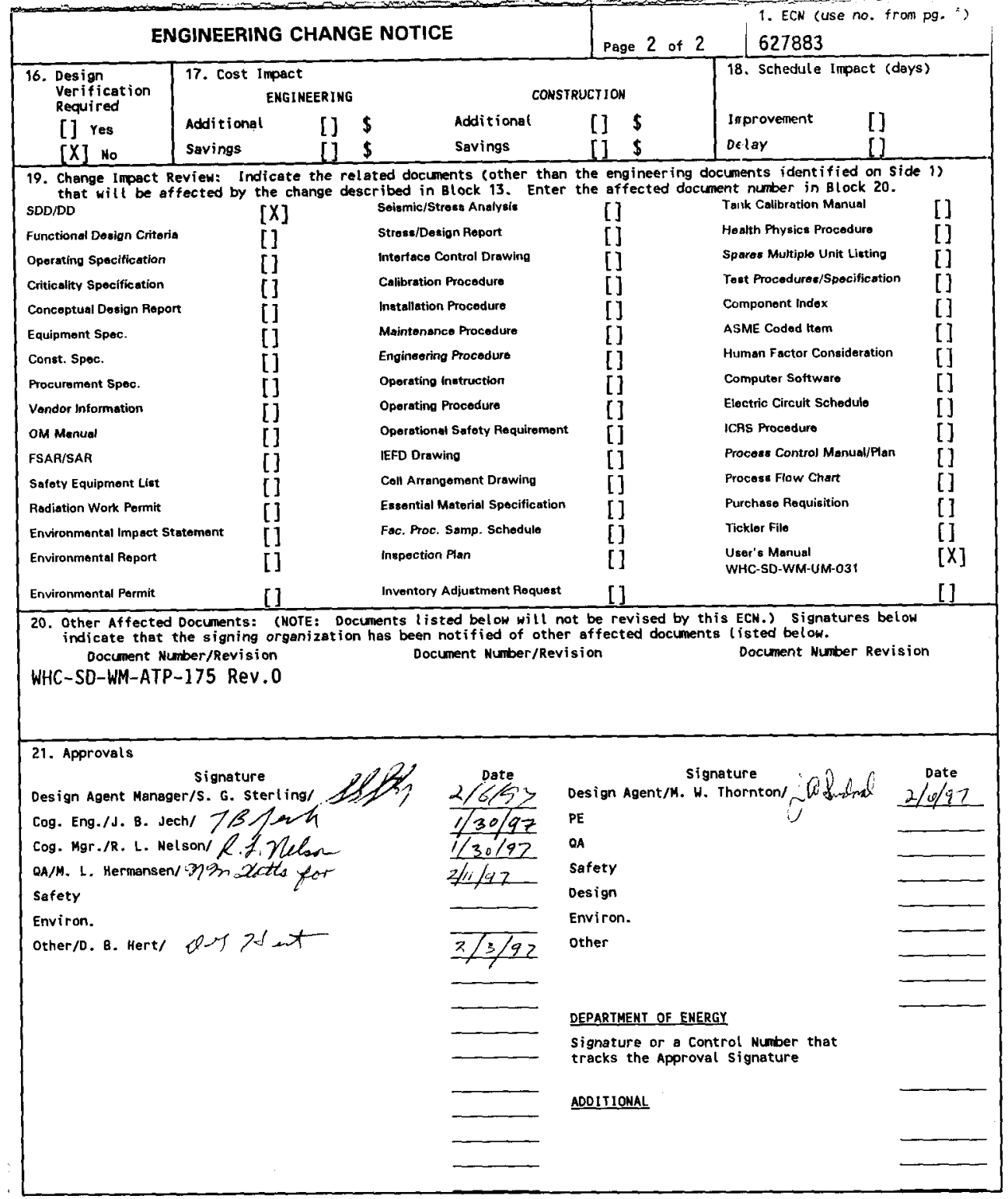




\title{
Acceptance Test Procedure For The Master Equipment List (MEL) Database System -- Phase I
}

\author{
M. W. Thornton \\ Fluor Daniel Northwest \\ P. O. Box 1050 \\ Richland, WA 99352 \\ U.S. Department of Energy Contract DE-AC06-87RL10930 \\ EDT/ECN: KN \\ Org Code: $77820 \quad$ Charge Code: N12A4 \\ B\&R Code: EW3120071 Total Pages: $\$ 345$
}

Key Words: Acceptance Test Procedure

Abstract: Approval and release of the Acceptance Test Procedure for the Master Equipment List (MEL) Phase I

TRADEMARK DISCLAIMER. Reference herein to any specific commercial product, process. or service by trade name. trademark. manufacturer. or otherwise, does not necessarily constitute or imply its endorsement, recommendation, or favoring by the united States Government or any agency thereof or its contractors or subcontractors.

Printed in the United States of America. To obtain copies of this document, contact: WHC/BCS Document Control Services, P.O. Box 1970. Mailstop H6-08. Richland WA 99352. Phone (509) 372-2420; Fax (509) 376-4989.
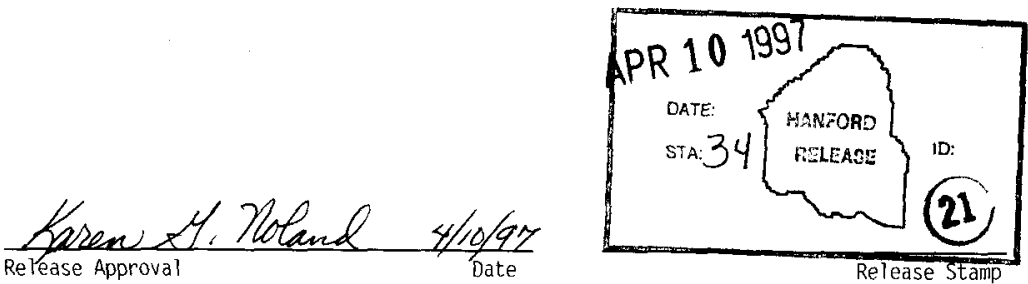

\section{Approved for Public Release}




\section{RECORD OF REVISION}

(1) Document Number

HNF-SD-WM-ATP- 175

(2) Title

Acceptance Test Procedure (ATP) for the Master Equipment List (MEL) Database System -Phase 1

\begin{tabular}{|c|c|c|c|}
\hline \multirow{2}{*}{$\begin{array}{l}(3) \\
\text { Revision }\end{array}$} & \multirow{2}{*}{$\begin{array}{l}\text { (4) Description of Change - Replace, Add, and Delete } \\
\text { Pages }\end{array}$} & \multicolumn{2}{|c|}{ Authorized for Release } \\
\hline & & $\begin{array}{l}\text { (5) Cog. } \\
\text { Engr. }\end{array}$ & (6) Cog. Mgr. Date \\
\hline 0 & (7) Related EDT Number is 611807 & JB Jech & RL Nelson \\
\hline 1 & $\begin{array}{l}\text { ECN is } 627878 \text { - Complete rewrite of Master } \\
\text { Equipment List (MEL) Database System -- } \\
\text { Phase } 1 \\
\text { As of } 1 / 7 / 97 \text { Document Number was changed } \\
\text { from WHC-SD-WM-ATP-175 to HNF-SD-WM-ATP-175 }\end{array}$ & JB Jech & $\begin{array}{l}\text { RL NeTson } \\
\text { Rqulelion }\end{array}$ \\
\hline 2 RS & ECN is 627883 - See Section 13a for changes & JB jech & RL Nelson T/3097 \\
\hline & & & \\
\hline & & & \\
\hline & & & \\
\hline & & & \\
\hline & & & \\
\hline & & & \\
\hline & & & \\
\hline & & & \\
\hline & & & \\
\hline & & & \\
\hline & & & \\
\hline & & & \\
\hline & & & \\
\hline & & & \\
\hline & & & \\
\hline & & & \\
\hline & & & \\
\hline & & & \\
\hline & & & \\
\hline & & & \\
\hline
\end{tabular}




\title{
ACCEPTANCE TEST PROCEDURE
}

\author{
FOR THE
}

\section{MASTER EQUIPMENT LIST (MEL) DATABASE SYSTEM--PHASE I}

\author{
Revision 2
}

Prepared by:

S. G. Sterling \& M. W. Thornton

Data Automation Engineering \& Services

Fluor Daniel Northwest

and

D. L. Marquez

InfoTech West

November 1996

Prepared for:

Lockheed Martin Hanford Corporation

P.O. Box 1500

Richland, Washington 99352 
TABLE OF CONTENTS

SECTION

PAGE

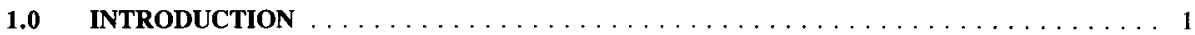

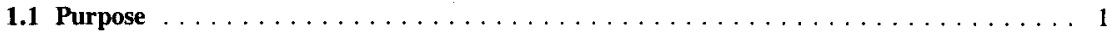

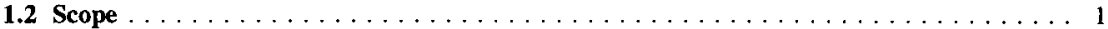

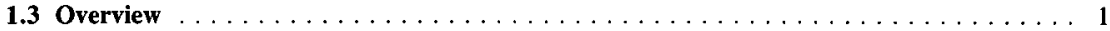

1.4 Definitions $\ldots \ldots \ldots \ldots \ldots \ldots \ldots \ldots \ldots \ldots \ldots \ldots \ldots \ldots \ldots \ldots \ldots$

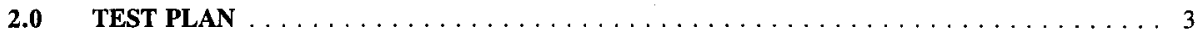

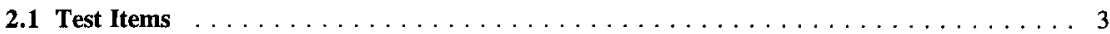

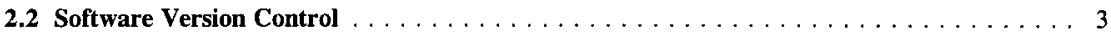

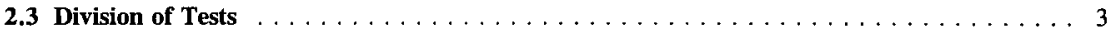

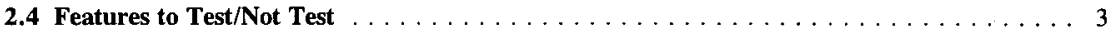

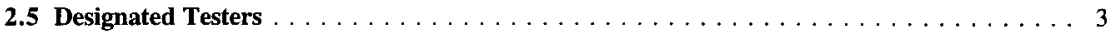

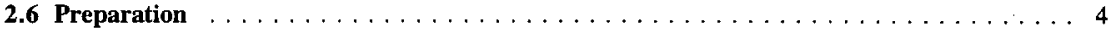

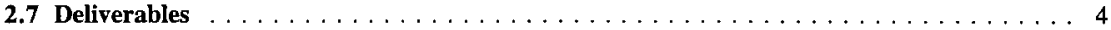

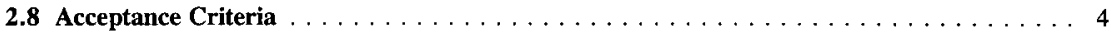

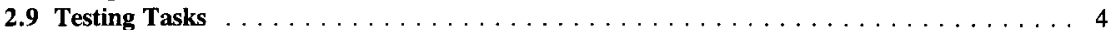

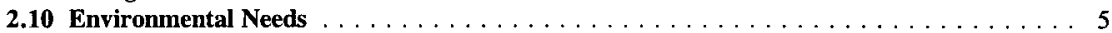

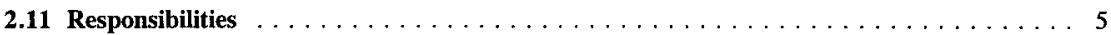

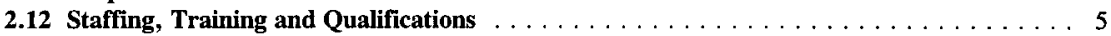

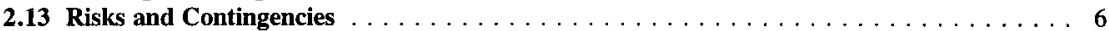

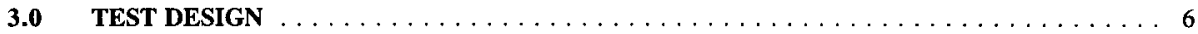

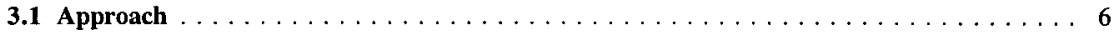

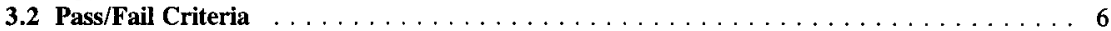

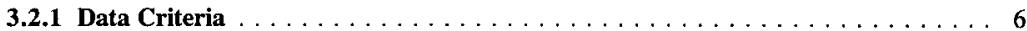

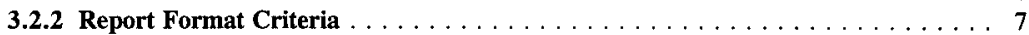

$4.0 \quad$ TEST PROCEDURES $\ldots \ldots \ldots \ldots \ldots \ldots \ldots \ldots \ldots \ldots \ldots \ldots \ldots$

$5.0 \quad$ TEST PROBLEM REPORT $\ldots \ldots \ldots \ldots \ldots \ldots \ldots \ldots \ldots \ldots \ldots \ldots$

6.0 ACCEPTANCE TEST REPORT $\ldots \ldots \ldots \ldots \ldots \ldots \ldots \ldots \ldots \ldots \ldots \ldots$

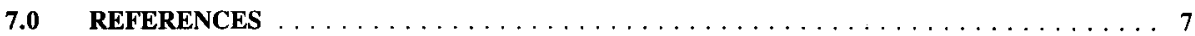

APPENDIX A ACCEPTANCE TEST PROCEDURE RECORD (SINGLE-USER) $\ldots \ldots \ldots \ldots$

APPENDIX B ACCEPTANCE TEST PROCEDURE RECORD (MULTI-USER) . . . . . . . . . . . B-1

\section{LIST OF TABLES}

Table 1. Organizational Responsibilities Matrix. $\ldots \ldots \ldots \ldots \ldots \ldots \ldots \ldots \ldots \ldots$ 


\section{ACCEPTANCE TEST PLAN \\ FOR THE \\ MASTER EQUIPMENT LIST (MEL) DATABASE SYSTEM}

\subsection{INTRODUCTION}

\subsection{Purpose}

The Waste Remediation System/../Facilities Configuration Management Integration group has requested development of a system to help resolve many of the difficulties associated with management of master equipment list information. This project has been identified as Master Equipment List (MEL) database system. Further definition is contained in the system requirements specification (SRS), reference 7.

\subsection{Scope}

This document satisfies the requirement for acceptance planning and acceptance testing as stated in the MEL Work Plan, reference 6.

After the acceptance testing has been completed, an Acceptance Test Report (ATR) describing the results of testing shall be issued.

\subsection{Overview}

This Acceptance Test Procedure (ATP) provides test plan information and defines the test procedures for the MEL. It includes the requirements and criteria as taken from the SRS, reference 7. The ATP has been prepared following the WHC-CM-3-10 "Software Practices" (ref. 3) guidelines. The ATP shall serve as the testing document to ensure the specific requirements of the MEL are met with regard to assurance of the accuracy and quality of data managed with MEL.

\subsection{Definitions}

The following are abbreviations and definitions of terms used in this document:

$\begin{array}{ll}\text { AD } & \text { Approval Designator } \\ \text { DAES } & \text { Data Automation Engineering \& Services Department/Fluor Daniel Northwest } \\ \text { ATP } & \text { Acceptance Test Plan } \\ \text { ATR } & \text { Acceptance Test Report } \\ \text { DOE } & \text { Department of Energy } \\ \text { ECN } & \text { Engineering Change Notice } \\ \text { EDT } & \text { Engineering Data Transmittal } \\ \text { FDNW } & \text { Fluor Daniel Northwest, Inc. } \\ \text { MEL } & \text { Master Equipment List (MEL) database system } \\ \text { HLAN } & \text { Hanford Local Area Network } \\ \text { LMHC } & \text { Lockheed Martin Hanford Corporation } \\ \text { OTP } & \text { Operability Test Procedure } \\ \text { OTR } & \text { Operability Test Report } \\ \text { QA } & \text { Quality Assurance } \\ \text { PC } & \text { Personal Computer }\end{array}$




$\begin{array}{ll}\text { RCR } & \text { Review Comment Record } \\ \text { SC } & \text { Safety Class } \\ \text { SCR } & \text { Software Change Request } \\ \text { SRS } & \text { System Requirements Specification } \\ \text { TS } & \text { Test Specifications }\end{array}$

Application -- The use of quality-affecting computer software, programs, models, or other computer items to perform engineering design analysis, calculations, scientific analysis, data acquisition or to operate hardware or facilities.

Approval Designator -- Defined in WHC-CM-3-5, section 12.7 (Ref. 2).

Computer Software -- A set of computer codes, procedures, rules, and associated documentation and data pertaining to the operation of computer systems. This includes user-provided instructions and data that implement preprogrammed algorithms in control systems; computer codes and data that shall reside in firmware, and when specified by the cognizant manager, user-provided instructions and data used by commercial software such as spread sheet and database packages.

Computer Software/System Requirements Specification -- The documentation of essential requirements (functions, performance, design constraints and attributes) of the computer software and its external interfaces.

Database -- A generic term referring to the storage of data by a computer in a certain data structure.

Design Agent -- Previously the project Cognizant Engineer under WHC-CM-6-1, Standard Engineering Practices (ref. 5) and WHC-CM-3-10, Software Practices (ref. 3.) was the lead engineer in the organization chartered with developing the product. Implementing procedure deviation is contained in ICFKH-CM-SRM 1.2D1, Manuals. Procedures, and Instructions, reference 11)

Engineering Practices -- Documented management methods (ref. 5) which establish the manner and the order for the performance of common configuration management practices relating to engineering tasks.

Lead Engineer -- Responsible engineer within the performing development organization that assumes Design Agent Engineer responsibility for development of the system.

Safety Class -- Defined in WHC-CM-4-46 (see ref. 1.)

Software Practices -- Documented management methods (3) which establish the manner and the order for the performance of common configuration management practices relating to software and systems engineering tasks.

Design_Authority -- Responsible engineer delegate of the system owner. Has responsibility for the system as defined by WHC-CM-6-1, Standard Engineering Practices, for the facility and user. Implementing procedure deviation is contained in ICFKH-CM-SRM 1.2D1, Manuals, Procedures, and Instructions, reference 11)

Quality Record -- A completed document that furnishes evidence of the quality of items and/or activities affecting quality. 


\subsection{TEST PLAN}

\subsection{Test Items}

This ATP is designed to test the functional requirements of the MEL and to determine whether or not they have been satisfied based on the defined Testing and Acceptance Criteria. The functional requirements can be found in the System Requirements Specification for Master Equipment List (MEL) database system (Ref. 7), Section 3.0 "SPECIFIC REQUIREMENTS". The test criteria is contained in Section 3.6.6, "Testing and Acceptance Criteria" of the same document. The requirements and criteria have been mapped into the procedures and test cases provided herein. Other related tests may also be performed.

\subsection{Software Version Control}

The software under test will be controlled. When the software is readied for acceptance testing, the version will be recorded and released. Backups of the released software will be prepared on optical discs and stored by the DAES Manager.

It is recognized that the ATP may be executed more than once if necessary due to the magnitude of changes required in the software. The version of the software will be incremented per the Configuration Management Plan (ref. 9) as changes are made. Each version that undergoes acceptance testing will be recorded, released, and copied to optical disc.

Software Revision Records are signed and kept in the project files, 1200 Jadwin, Suite 16, Room 11.

\subsection{Division of Tests}

The ATP is designed to be performed in two parts - a single-user test which emphasizes the details of the system functionality, and a multi-user test which focuses on the system's ability to support multiple concurrent users utilizing specific sets of functions. Some tests in these two parts will overlap by testing the same system functions. The single-user test will be performed with version 1.32 of the MEL Phase I. The multi-user test will be performed on version 1.33. The version change accounts for minor updates made to correct isolated problems found in the single user test that will be retested in the multi-user test.

The single-user part of the ATP will be performed prior to the multi-user test with enough time between them to resolve problems encountered.

\subsection{Features to Test/Not Test}

Each test/test-case listed in the Acceptance Test Procedure \& Record (Appendix A) identifies the Tester by the name of the Design Authority representative, or as 'Deferred' by that representative, or as "Multiple Users". Those marked by the representative's name will be performed in the single-user part of the ATP. Those marked as "Multiple Users" will be performed in the multi-user part of the ATP. Those marked as "Deferred" will not be performed.

Deferrals are indicated where test cases will not be performed until a later version of the software. These test cases are included in the ATP for completeness. The SCR log includes a list of specific functions that are being deferred to future versions, and why. In general, these deferrals are the decision of the customer based upon available time, budget, and priority of need.

\subsection{Designated Testers}

The single-user ATP will be performed by a Design Authority (LMHC, Facilities Configuration Management Integration) representative and will be witnessed by a Design Agent (FDNW, Data Automation 
Engineering) representative. Together, these key testers will record the test findings. The multi-user test will be conducted jointly by the same representatives with an additional 5 to 10 testers selected by the Design Authority representative. All testers will record test findings. The ATR will be prepared by the key testers.

\subsection{Preparation}

Testers will be prepared for executing the ATP. The key testers, performing the single-user ATP, will have considerable experience with the software application as beta testers. The multi-user ATP testers have been trained specifically for their roles in testing. The training was a 4-hour session ( 2 of them with 6 to 8 participants each) including written materials, hands-on experience using the pre-test version of the software. Trainees were instructed on use of the software, their roles in the test, and how to prepare problem reports.

The training materials were designed to meet the requirements of TWRS Training. A TWRS Training representative reviewed and accepted these materials for pre-release use and participated in these early training sessions. These modules, and the User Guide for the MEL version 1.0, will be the basis of the User Guide for version 2.0. Due to schedule constraints, the customer has agreed to defer final preparation of the User Guide until after the release of version 2.0 - to be included in a subsequent release within the next 6 months. These modules will also be the basis for the formal Training Plan and Modules currently under development.

\subsection{Deliverables} MEL.

The following items shall be delivered by the key testers upon completion of the acceptance testing for

1) An Acceptance Test Procedure Record.

2) Any problem reports completed by the testers.

3) An Acceptance Test Report complete with the Acceptance Test Procedure Record and problem reports completed during acceptance testing.

4) Problem reports will be recorded in the Software Change Request (SCR) database established for the MEL project.

\subsection{Acceptance Criteria}

All tests shall be performed according to criteria defined on the test procedure record without any unresolved functional exceptions. Test results shall be approved by the Change Control Board (CCB) defined in the MEL Configuration Management Plan, reference 9.

\subsection{Testing Tasks}

\section{Hardware Setup}

- The required hardware shall be setup and available prior to the performance of the ATP. Minimum equipment is specified as a PC-compatible with $486 / 33$ processor, $8 \mathrm{mb}$ of random access memory and $30 \mathrm{mb}$ of free hard disk space.

\section{Software Setup}

- All required software shall be installed per appropriate installation procedures. 
MEL Database

- The databases shall be loaded only with initial master data sets so that only known data is in the database.

- The database and application software shall have been previously configured for the ATP test stations.

- At completion of the ATP, all files shall be emptied because the data input during this test is only test data and has no value outside the test. The master data sets shall also be emptied and the MEL loaded with verifiable data.

\subsection{Environmental Needs}

The equipment needed to perform acceptance testing is as follows:

a) Configured Personal Computer (PC) workstation.

b) Attachment to the site HLAN.

c) Established user account on the server with appropriate access rights.

d) A LaserJet III or higher and paper for the printer.

e) General office supplies for testing support.

\subsection{Responsibilities}

Organizations involved with MEL Acceptance Testing are those listed in the Configuration Management Plan, reference 9.

\section{Table 1. Organizational Responsibilities Matrix.}

\begin{tabular}{||l|l|l|l|}
\hline DESCRIPTION & $\begin{array}{l}\text { ESQ/../ } \\
\text { QA }\end{array}$ & $\begin{array}{l}\text { Design } \\
\text { Authority }\end{array}$ & $\begin{array}{l}\text { Lead } \\
\text { Engineer }\end{array}$ \\
\hline 1. Acceptance Test Plan & 3,4 & $2,3,4$ & $1,2,3,4$ \\
\hline 2. Acceptance Test & & 2 & 1,2 \\
\hline 3. Acceptance Test Report & 3,4 & $2,3,4$ & $1,2,3,4$ \\
\hline
\end{tabular}

$1=$ Initiates

2 = Provides Input

$3=$ Reviews

$4=$ Approves

\subsection{Staffing, Training and Qualifications}


Testing personnel shall be from within or a contractor to Data Automation Engineering \& Services (DAES), and Plant Configuration \& Drawings (PC\&D). Testers shall be independent (not involved with the implementation of the sub-component being tested).

The tester shall have some familiarity with the Windows environment and a minimum one year experience with database applications. This includes the ability to successfully use windows, check boxes, menu bars, etc. However, this ATP is designed so testers shall need minimal training of the MEL application.

During acceptance testing, any questions that arise regarding the use of the MEL system shall be answered as needed by the development team.

\subsection{Risks and Contingencies}

Acceptance testing shall be performed on test data in a version and data set separated from live production system and data.

\subsection{TEST DESIGN}

\subsection{Approach}

This acceptance test procedure and associated acceptance test procedure record was based and is traceable to the SRS. For each identifiable and traceable requirement, there are one or more test items, each identified with a Test ID number (e.g. T1.003) and test item description. For each test item, there are one or more test procedures. Each test procedure has a procedure ID and test procedure description. Also for each test item, there are one or more test cases. For each test case, there is a test case ID and test case description. Each test case is tested, and the test result (pass or fail,) date, time, and initials of tester is placed on the acceptance test procedure record.

The acceptance testing of the specific requirements for MEL is to be to the best extent possible without unnecessary retesting. All specific requirements for MEL are to be tested.

This ATP is written to give the tester flexibility in selecting test data. Any data that is used to test the system shall be documented by the tester into the test log. The purpose of journalizing test data is to ensure the system is maintaining and reporting correct data. The tester is responsible for ensuring that all data meets the data requirements listed in the requirements document. The tester is also responsible for ensuring that the data is reported according to the requirements document for the Master Equipment List (MEL) database system. Any data inputs that create a system error shall also be documented by the tester. This shall provide information to help the developmental team track the error and perform the necessary corrections.

Hold points are not defined for this test. If testing must stop due to a failure that inhibits further testing, the test can be placed on hold. The decision to restart the test from the hold point will be made by CCB based upon the changes made to correct the impasse.

\subsection{Pass/Fail Criteria}

If a particular test case meets the functional requirement; based on criteria shown or referenced, it shall pass. If a particular test case does not meet all of the functional requirement, it shall be failed. On review, the CCB may disposition any test case.

\subsubsection{Data Criteria}


All criteria for data can be found in section 3.6.1 "Data" of the SRS for MEL (Ref. 7) and Appendix A of the same document.

\subsubsection{Report Format Criteria}

All report format criteria can be found in section 3.2.4 "Report Functions" of the SRS for MEL (Ref. 7).

\subsection{TEST PROCEDURES}

Test procedures are specified in the acceptance test procedure record. Pass/fail, date, time, and tester information shall be recorded on the acceptance test procedure record to be provided to the tester. The test procedure record shall be treated as a quality record.

\subsection{TEST PROBLEM REPORT}

Any test failures shall be documented on a System Change Request/Problem Report as described in the MEL Configuration Management Plan, reference 9. The sheet shall be filled out in detail, with the SCR/PR number recorded under "test result" on the acceptance test procedure record.

\subsection{ACCEPTANCE TEST REPORT}

Upon completion of the Acceptance Test and recording of the results, an Acceptance Test Report (ATR) will be prepared for review and approval. The ATR will include;

- A summary description of the test results,

- A copy of the SCR log which will record all problems,

- Definitions of terms used in the SCR $\log$,

- Conditions for release of the software to become version 2.0, and

- An explanation of how final exceptions will be resolved, retested, and passed.

\subsection{REFERENCES}

1. WHC-CM-4-46, Non-Nuclear Facilities Safety Analysis Manual, February 1996.

2. WHC-CM-3-5, Document Control and Records Management Manual.

Section 12.7, Rev. 0, "Approval of Environmental, Safety, and Quality Affecting Documents", February 1, 1994.

3. WHC-CM-3-10, Software Practices.

SP-3.3, Rev. 0, "Testing," January 31, 1993.

SP-6.1, Rev. 0, "Document Control," January 31, 1993.

SP-6.2, Rev. 0, "Software Control," January 31, 1993.

SP-6.3, Rev. 0, "Change Request and Problem Report," January 31, 1993.

Appendix J, Rev. 0, "System Test Documentation," January 31, 1993. 
4. WHC-CM-4-2, Quality Assurance Manual.

QR-3.0, Rev. 5, "Design Control," September 30, 1993.

QR-19.0, Rev. 1, "Software Quality Assurance Requirements," September 30, 1993.

5. WHC-CM-6-1, Standard Engineering Practices.

EP-2.2, Rev. 7, "Engineering Document Change Control", August 5, 1994.

EP-4.1, Rev. 5, "Design Verification Requirements", May 27, 1994.

6. WHC-SD-WHE-SDP-012, Software Development Plan (Work Plan) for MEL-Phase 1, Rev. 0, J. B. Jech, November, 1995.

7. WHC-SD-WM-CSRS-023, System Requirements Specification For The Master Equipment List - Phase 1, Rev. 1, J. B. Jech, April, 1995.

8. WHC-SD-WE-SDD-065, System Design Description for the Master Equipment List, C. D. Starghill and M. W. Thornton, Rev A, TBD.

9. WHC-SD-WM-CSCM-033, Master Equipment List Configuration Management Plan, S. G. Sterling, Rev. 0, March 1996

10. ICFKH-CM-SRM 1.2D1, Manuals. Procedures, and Instructions, October 25, 1996. 
APPENDIX A ACCEPTANCE TEST PROCEDURE RECORD (SINGLE-USER) 


\section{Master Equipment List Database Phase 1 Acceptance Test Procedure \& Record}

Version 1.32

$11 / 21 / 96$

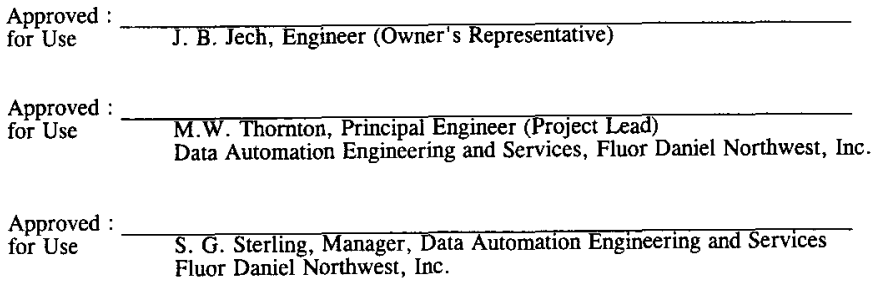




\section{Master Equipment List Database \\ Phase 1 \\ Acceptance Test Procedure \& Record}

Requirement ID: $\quad$ R3.1, B3

Requirement Ref : $\quad$ SRS 3.1 (bullet 3), Gen Reqs (Acc Criteria \#3)

Requirement Description : The MEL Phase 1 Application code shall provide comments to support future code changes.

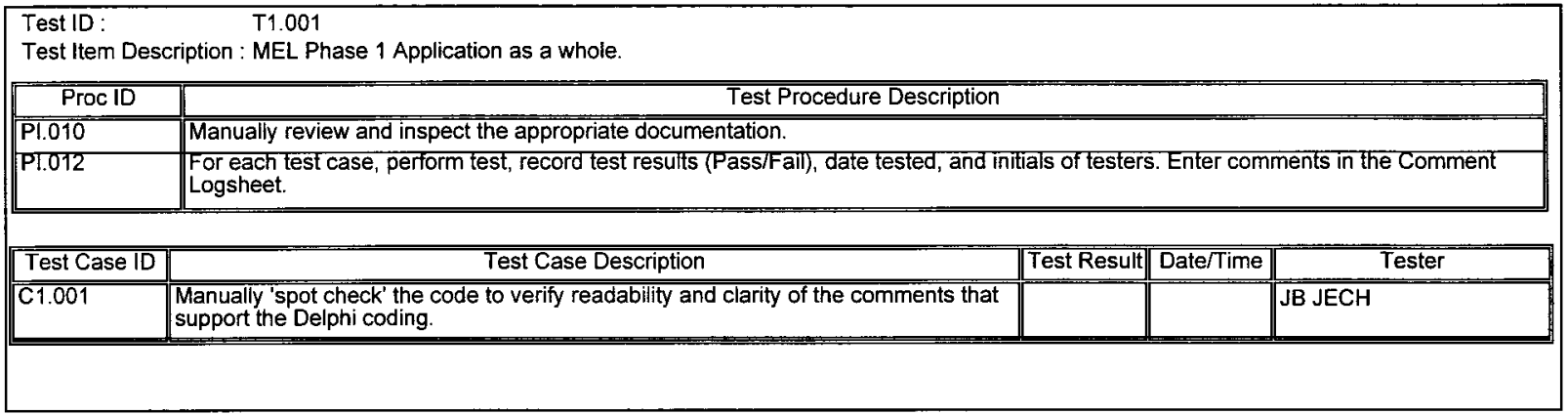

\section{Requirement ID: $\quad$ R3.1, B4}

Requirement Ref : $\quad$ SRS 3.1 (bullet 4), Gen Reqs (Acc Criteria \#1)

Requirement Description : The MEL Phase 1 Application shall have user-friendly features integrated throughout the $\mathrm{Db}$. 


\section{Master Equipment List Database Phase 1 \\ Acceptance Test Procedure \& Record}

\begin{tabular}{|c|c|c|c|c|}
\hline \multicolumn{5}{|c|}{$\begin{array}{ll}\text { Test ID : } & \text { T1.002 } \\
\text { Test Item Description : MEL Phase } 1 \text { Application as a whole (supports User-Friendly Interface). }\end{array}$} \\
\hline PI.003 & \multicolumn{4}{|l|}{ Operate the application exercising appropriate functions and features. } \\
\hline PI.012 & \multicolumn{4}{|c|}{$\begin{array}{l}\text { For each test case, perform test, record test results (Pass/Fail), date tested, and initials of testers. Enter comments in the Comment } \\
\text { Logsheet. }\end{array}$} \\
\hline Test Case ID & Test Case Description & Test Result & Date/Time & Tester \\
\hline$\overline{\mathrm{C} 1.300}$ & $\begin{array}{l}\text { Verify that windows and menus provide navigation to appropriate Folders and their } \\
\text { associated mini-screens or drop-down lists. }\end{array}$ & & & $\mathrm{JB} \mathrm{JECH}$ \\
\hline C1.301 & Verify on-line hint (yellow) boxes provide correct field definitions. & & & JB JECH \\
\hline C1.302 & Verify user/error mini-screens make sense. & & & JB JECH \\
\hline C1.303 & Verity mouse and key drive the selection for windows, menus, and tool bar buttons. & & & JB JECH \\
\hline C1.306 & Verify the menu/tool bar buttons provide navigation to exit. & & & JB JECH \\
\hline C1.307 & Verify Help buttons provide on-line ässistance. & & & DEFER PER JB JECH \\
\hline
\end{tabular}

Requirement ID

Requirement Ref :

SRS 3.1 (bullet 5), Gen Reqs (Acc Criteria \#4)

Requirement Description : The MEL Phase 1 Application shall support a multiple user and multiple task environment. 


\section{Master Equipment List Database \\ Phase 1 \\ Acceptance Test Procedure \& Record}

HNF-SD-WM-ATP-175, Rev. 2

\begin{tabular}{|c|c|c|c|}
\hline \multicolumn{4}{|c|}{$\begin{array}{l}\text { Test ID : } \\
\text { Test Item Description : MEL Phase } 1 \text { Application as a whole (supports Multiple Tasks). }\end{array}$} \\
\hline PI.003 $=$ & \multirow{2}{*}{\multicolumn{3}{|c|}{$\begin{array}{l}\text { Operate the application exercising appropriate functions and features. } \\
\text { For each test case, perform test, record test results (Pass/Fail), date tested, and initials of testers. Enter comments in the Comment } \\
\text { Logsheet. }\end{array}$}} \\
\hline Pा.012 & & & \\
\hline Test Case ID & Test Case Description & Test Result Date/Time & Tester \\
\hline $\mathrm{C} 1.008=$ & $\begin{array}{l}\text { Ensure the system enables operation of multiple tasks and that they can be } \\
\text { performed concurrently. }\end{array}$ & & MULTIPLE USERS \\
\hline$C 7.400$ & $\begin{array}{l}\text { Ensure the system can manage multiple queries, Fodder viewing, and multiple } \\
\text { reporting. }\end{array}$ & & MULTIPLE USERS \\
\hline C1.401 & $\begin{array}{l}\text { Ensure the system can manage, concurrently, the multi Editllock sessions and multif } \\
\text { Posts/Cancels. Verify posted changes are in View mode and in Change Log. }\end{array}$ & & MULTIPLE USERS \\
\hline C1.402 & $\begin{array}{l}\text { Ensure the system can manage, concurrently, the multi EditLock sessions and view } \\
\text { the pending changes. }\end{array}$ & & MULTIPLE USERS \\
\hline C1.403 & Ensure the system can manage the locked record functionality. & & MULTIPLE USERS \\
\hline C1.404 & Ensure the system can manage multiple Finds and Quick Searches. & & MULTIPLE USERS \\
\hline C1.407 & $\begin{array}{l}\text { Ensure the system can support rüning itself and multiple sotwware applications } \\
\text { concurrently. }\end{array}$ & & MULTIPLE USERS \\
\hline $\mathrm{C} 1.502$ & $\begin{array}{l}\text { Verify that multiple users (5-70) can concurrently log onto the system, remain logged } \\
\text { on, and utilize the application's functions without failure. }\end{array}$ & & MULTIPLE USERS \\
\hline
\end{tabular}




\section{Master Equipment List Database \\ Phase 1 \\ Acceptance Test Procedure \& Record}

\begin{tabular}{|c|c|c|c|}
\hline \multicolumn{4}{|c|}{$\begin{array}{l}\text { Test ID : } \\
\text { Test Item Description : MEL Phase } 1 \text { Application as a whole (supports Multiple Users). }\end{array}$} \\
\hline Proc ID & \multicolumn{3}{|l|}{ Test Procedure Description } \\
\hline PI.003 & \multicolumn{3}{|l|}{ Operate the application exercising appropriate functions and features. } \\
\hline P.012 & \multicolumn{3}{|c|}{$\begin{array}{l}\text { For each test case, perform test, record test results (Pass/Fail), date tested, and initials of testers. Enter comments in the Comment } \\
\text { Logsheet. }\end{array}$} \\
\hline Test Case ID & Test Case Description & Test Result Date/Time & Tester \\
\hline$\overline{C 1.009}=$ & $\begin{array}{l}\text { Ensure the system enables operation of multiple users and that various access } \\
\text { levels can be logged on concurrently. }\end{array}$ & & MULTIPLE USERS \\
\hline C1.405 & $\begin{array}{l}\text { Ensure the system can manage, concurrently, Label Administrator and System } \\
\text { Administrator creating a new EIN. }\end{array}$ & & MULTIPLE USERS \\
\hline C1.406 & $\begin{array}{l}\text { Ensure the system can manage a System Administrator's functionalities in a } \\
\text { concurrent session with multiple users. }\end{array}$ & & MULTIPLE USERS \\
\hline C.4.407 & $\begin{array}{l}\text { Ensure the system can support running itself and multiple sottware applications } \\
\text { concurrently. }\end{array}$ & & MULTIPLE USERS \\
\hline $\mathrm{C} 1.500$ & $\begin{array}{l}\text { Verify that a user can log on as a Read Only user while another logs on as an Edit } \\
\text { user with tester-chosen privileges. }\end{array}$ & & MULTIPLE USERS \\
\hline C1.501 & $\begin{array}{l}\text { Verify that a user can log on as a Label Administrator user while another logs on as } \\
\text { a System Administrator user. }\end{array}$ & & MULTIPLE USERS \\
\hline C1.502 & $\begin{array}{l}\text { Verify that multiple users (5-10) can concurrently log onto the system, remain logged } \\
\text { on, and utilize the application's functions without failure. }\end{array}$ & & MULTIPLE USERS \\
\hline
\end{tabular}

Requirement ID :

Requirement Ref :

Requirement Description : The MEL Phase 1 Application shall support query selections/modifications and print query-selected reports. 


\section{Master Equipment List Database \\ Phase 1 \\ Acceptance Test Procedure \& Record}

HNF-SD-WM-ATP-175, Rev. 2

\begin{tabular}{|l|l|l||l||}
\hline Test ID : & T1.010 \\
Test Item Description : One or more tester-chosen query selections for tester-chosen privileges. \\
\hline PI.007
\end{tabular}

Requirement ID :

Requirement Ref :

R3.1, B7

Requirement Description : The MEL Phase 1 Application shall operate efficiently in the HLAN environment. 


\section{Master Equipment List Database Phase 1 \\ Acceptance Test Procedure \& Record}

\begin{tabular}{||l|l|l|l|l|}
\hline Test ID : & T1.023 \\
Test Item Description : MEL Phase 1 Application as a whole (supports HLAN standard/ESOE environment operation efficiency). \\
\hline PI.001
\end{tabular}

Requirement ID

Requirement Ref :
R3.1, B8

SRS 3.1 (bullet 8), Gen Reqs (Acc Criteria \#7, 8)

Requirement Description : The MEL Phase 1 Application shall support control access using passwords. 


\section{Acceptance Test Procedure \& Record}

\begin{tabular}{|c|c|c|c|}
\hline \multicolumn{4}{|c|}{$\begin{array}{ll}\text { Test ID : } & \text { T1.014 } \\
\text { Test Item Description : Privilege as a Data Entry User. }\end{array}$} \\
\hline Proc ID & \multicolumn{3}{|l|}{ Test Procedure Description } \\
\hline P1.002 & \multicolumn{3}{|l|}{ Launch application using access privilege. } \\
\hline P1.003 & \multicolumn{3}{|l|}{ Operate the application exercising appropriate functions and features. } \\
\hline PI.004 & \multicolumn{3}{|l|}{ Enter new information in the MEL Phase 1 Application. } \\
\hline PI.012 & \multicolumn{3}{|c|}{$\begin{array}{l}\text { For each test case, perorm test, record test results (Pass/Fail), date tested, and initials of testers. Enter comments in the Comment } \\
\text { Logsheet. }\end{array}$} \\
\hline Test Case ID & Test Case Description & \begin{tabular}{|l|l|} 
Test Result & Date/Time \\
\end{tabular} & Tester \\
\hline$\overline{C 1.201}$ & $\begin{array}{l}\text { Verify the user can launch the application, log on, and ensure the application is } \\
\text { operable. }\end{array}$ & & JB JECH \\
\hline $\mathrm{C} 1.202$ & Verify that access is accomplished with appropriate access privileges. & & JB JECH \\
\hline $\mathrm{C} 1.204$ & Verify that use of appropriate User ID/Password enable entry authorizations. & & JB JECH \\
\hline $\mathrm{C} .212$ & $\begin{array}{l}\text { Verify a new EIN can be created (using appropriate privilege) and posted and is } \\
\text { present in View mode. }\end{array}$ & & JB JECH \\
\hline C1.213 & $\begin{array}{l}\text { Verify appropriate information can be edited in a specific Folder by selecting the field } \\
\text { and initializing the edit with the right mouse button. }\end{array}$ & & JB JECH \\
\hline $\mathrm{C} .215$ & $\begin{array}{l}\text { Verify that pending changes and locked records are identifed by color and are } \\
\text { available to print out. }\end{array}$ & & JB JECH \\
\hline C1.216 & $\begin{array}{l}\text { Verify that the pending changes can be posted or cancelled and the change is } \\
\text { present in View mode. }\end{array}$ & & JB JECH \\
\hline $\mathrm{C} 1.217$ & Verify a new EIN can be expored in a tester-chosen format and retrieved. & & JB JECH \\
\hline $\mathrm{C} 1.300$ & $\begin{array}{l}\text { Verify that windows and menus provide navigation to appropriate Folders and their } \\
\text { associated mini-screens or drop-down lists. }\end{array}$ & & JB JECH \\
\hline C1.301 & Verify on-line hint (yellow) boxes provide correct field definitions. & & JB JECH \\
\hline $\mathrm{C} 1.302$ & Verify user/error mini-screens make sense. & & JB JECH \\
\hline C1.303 & Verify mouse and key drive the selection for windows, menus, and tool bar buttons. & & JB JECH \\
\hline C1.304 & $\begin{array}{l}\text { Verify the operation of the system is interactive, providing immediate processing of } \\
\text { actions. }\end{array}$ & & JB JECH \\
\hline C1.305 & $\begin{array}{l}\text { Verify the system can manage itself by displaying system resources and continue to } \\
\text { be operable in the HLAN standard/ESOE environment. }\end{array}$ & & JB JECH \\
\hline C1.306 & Verify the menu/tool bar buttons provide navigation to exit. & & JB JECH \\
\hline
\end{tabular}




\section{Acceptance Test Procedure \& Record}

\begin{tabular}{|c|c|c|c|}
\hline \multicolumn{4}{|c|}{$\begin{array}{l}\text { Test ID: } \quad \text { T1.015 } \\
\text { Test Item Description : Privifege as a Data Editor User. }\end{array}$} \\
\hline Proc ID & \multicolumn{3}{|l|}{ Test Procedure Description } \\
\hline PI.002 & \multicolumn{3}{|l|}{ Launch application using access privilege. } \\
\hline PI.003 & \multicolumn{3}{|l|}{ Operate the application exercising appropriate functions and features. } \\
\hline Pा.005 & \multicolumn{3}{|l|}{ Select and edit information via appropriate folders or windows. } \\
\hline Pा.012 & \multicolumn{3}{|c|}{$\begin{array}{l}\text { For each test case, perform test, record test results (Pass/Fail), date tested, and initials of testers. Enter comments in the Comment } \\
\text { Logsheet. }\end{array}$} \\
\hline Test Case ID & Test Case Description & |Test Result|| Date/Time & $\overline{\text { Tester }}$ \\
\hline$\overline{c 1.201}$ & $\begin{array}{l}\text { Verify the user can launch the application, log on, and ensure the application is } \\
\text { operable. }\end{array}$ & & JB JECH \\
\hline C1.202 & Verify that access is accomplished with appropriate access privileges. & & JB JECH \\
\hline $\mathrm{C} 1.203$ & Verify that use of appropriate User ID/Password enable editing authorization. & & JB JECH \\
\hline C1.211 & $\begin{array}{l}\text { Select Folder (Pointer/References/Nameplate/Specifications/Safety) and verify it } \\
\text { was the Folder selected. }\end{array}$ & & JB JECH \\
\hline C1.213 & $\begin{array}{l}\text { Verify appropriate information can be edited in a specific Folder by selecting the field } \\
\text { and initializing the edit with the right mouse button. }\end{array}$ & & JB JECH \\
\hline $\mathrm{C} 1.214$ & $\begin{array}{l}\text { Verify that the edited information can be viewed and verify changes are pending by } \\
\text { initializing the right mouse button and icon. }\end{array}$ & & JB JECH \\
\hline C1.215 & $\begin{array}{l}\text { Verify that pending changes and locked records are identifed by color and are } \\
\text { available to print out. }\end{array}$ & & JB JECH \\
\hline C1.216 & $\begin{array}{l}\text { Verify that the pending changes can be posted or cancelled and the change is } \\
\text { present in View mode. }\end{array}$ & & JB JECH \\
\hline C1.300 & $\begin{array}{l}\text { Verify that windows and menus provide navigation to appropriate Folders and their } \\
\text { associated mini-screens or drop-down lists. }\end{array}$ & & $\overline{\mathrm{JB}} \mathrm{JECH}$ \\
\hline C1.301 & Verify on-line hint (yeliow) boxes provide correct field definitions. & & JB JECH \\
\hline C1.302 & Verify user/error mini-screens make sense. & & JB JECH \\
\hline C1.303 & Verify mouse and key drive the selection for windows, menus, and tool bar buttons. & & JB JECH \\
\hline C1.304 & $\begin{array}{l}\text { Verify the operation of the system is interactive, providing immediate processing of } \\
\text { actions. }\end{array}$ & & JB JECH \\
\hline C1.305 & $\begin{array}{l}\text { Verify the system can manage itself by displaying system resources and continue to } \\
\text { be operable in the HLAN standard/ESOE environment. }\end{array}$ & & JB JECH \\
\hline C1.306 & Verify the menu/tool bar buttons provide navigation to exit. & & $\overline{\mathrm{JB}} \mathrm{JECH}$ \\
\hline
\end{tabular}




\begin{tabular}{|c|c|c|c|c|}
\hline \multicolumn{5}{|c|}{$\begin{array}{ll}\text { Test ID: } & \text { T1.016 } \\
\text { Test Item Description : Privilege as a System Administrator User. }\end{array}$} \\
\hline Proc ID & \multicolumn{4}{|l|}{ Test Procedure Description } \\
\hline PI.002 & \multicolumn{4}{|l|}{ Launch application using access privilege. } \\
\hline Pि.003 & \multicolumn{4}{|l|}{ Operate the application exercising appropriate functions and features. } \\
\hline Pा.004 & \multicolumn{4}{|l|}{ Enter new information in the MEL Phase 1 Application. } \\
\hline PI.005 & \multicolumn{4}{|l|}{ Select and edit information via appropriate foldērs or windows. } \\
\hline PI.006 & \multicolumn{4}{|c|}{ View information via appropriate folders or windows. } \\
\hline Pा.012 & \multicolumn{4}{|c|}{$\begin{array}{l}\text { For each test case, perorm test, record test results (Pass/Fail), date tested, and initials of testers. Enter comments in the Comment } \\
\text { Logsheet. }\end{array}$} \\
\hline Test Case [D & Test Case Description & Test Result & Date/Time & Tester \\
\hline C1.122 & Verify that System Admin. can track user changes. & & & JB JECH \\
\hline C1.123 & Verify that System Admin. can assign user access information. & & & JB JECH \\
\hline C1.201 & $\begin{array}{l}\text { Verify the user can launch the application, log on, and ensure the application is } \\
\text { operable. }\end{array}$ & & & JB JECH \\
\hline C1.202 & Verify that access is accomplished with appropriate access privileges. & & & JB JECH \\
\hline C1.207 & $\begin{array}{l}\text { Verify that use of appropriate UserTD/Password enable System Admin. } \\
\text { authorizations. }\end{array}$ & & & JB JECH \\
\hline C1.208 & Verify that System Admin. can maintain definition lists. & & & JB JECH \\
\hline $\mathrm{C} 1.300$ & $\begin{array}{l}\text { Verify that windows and menus provide navigation to appropriate Folders and their } \\
\text { associated mini-screens or drop-down lists. }\end{array}$ & & & JB JECH \\
\hline C1.301 & Verify on-line hint (yellow) boxes provide correct field definitions. & & & JB JECH \\
\hline C1.302 & Verify user/error mini-screens make sense. & & & JB JECH \\
\hline C1.303 & Verify mouse and key drive the selection for windows, menus, and tool bar buttons. & & & $J \bar{B} \overline{J E} \overline{C H}$ \\
\hline C1.304 & $\begin{array}{l}\text { Verify the operation of the system is interactive, providing immediate processing of } \\
\text { actions. }\end{array}$ & & & JB JECH \\
\hline C1.305 & $\begin{array}{l}\text { Verify the system can manage itself by displaying system resources and continue to } \\
\text { be operable in the HLAN standard/ESOE environment. }\end{array}$ & & & JB JECH \\
\hline C1.306 & Verify the menu/tool bar buttons provide navigation to exit. & & & JB JECH \\
\hline
\end{tabular}




\section{Acceptance Test Procedure \& Record}

\begin{tabular}{|c|c|c|c|}
\hline \multicolumn{4}{|c|}{$\begin{array}{ll}\text { Test ID : } & \text { T1.017 } \\
\text { Test Item Description : Privilege as a Label Administrator User. }\end{array}$} \\
\hline$\overline{\mathrm{PI}} .002$ & \multicolumn{3}{|l|}{ Launch application using access privilege. } \\
\hline PT.003 & \multicolumn{3}{|l|}{ Operate the application exercising appropriate functions and features. } \\
\hline PI.004 & \multicolumn{3}{|l|}{ Enter new information in the MEL Phase 1 Application. } \\
\hline PI.005 & \multicolumn{3}{|l|}{ Select and edit information via appropriate folders or windows. } \\
\hline P1.006 & \multicolumn{3}{|c|}{ View information via appropriate folders or windows. } \\
\hline PI.012 & \multicolumn{3}{|c|}{$\begin{array}{l}\text { For each test case, perform test, record test results (Pass/Fail), date tested, and initials of testers. Enter comments in the Comment } \\
\text { Logsheet. }\end{array}$} \\
\hline Test Case ID & Test Case Description & Test Result Date/Time & Tester \\
\hline$\overline{C 1.201}$ & $\begin{array}{l}\text { Verify the user can launch the application, log on, and ensure the application is } \\
\text { operable. }\end{array}$ & & JB JECH \\
\hline C1.202 & Verify that access is accomplished with appropriate access privileges. & & JB JECH \\
\hline C1.205 & Verify that use of appropriate User ID/Password enable Label Admin. authorizations. & & JB JECH \\
\hline $\mathrm{C} 1.212$ & $\begin{array}{l}\text { Verify a new EIN can be created (using appropriate privilege) and posted and is } \\
\text { present in View mode. }\end{array}$ & & JB JECH \\
\hline C1.213 & $\begin{array}{l}\text { Verify appropriate information can be edited in a specific Folder by selecting the field } \\
\text { and initializing the edit with the right mouse button. }\end{array}$ & & $\mathrm{JB}$ JECH \\
\hline C1.216 & $\begin{array}{l}\text { Verify that the pending changes can be posted or cancelled and the change is } \\
\text { present in View mode. }\end{array}$ & & JB JECH \\
\hline C1.217 & Verify a new EIN can be exported in a tester-chosen format and retrieved. & & JB JECH \\
\hline C1.300 & $\begin{array}{l}\text { Verify that windows and menus provide navigation to appropriate Folders and their } \\
\text { associated mini-screens or drop-down lists. }\end{array}$ & & $\mathrm{JB} \mathrm{JECH}$ \\
\hline C1.301 & Verify on-line hint (yellow) boxes provide correct field definitions. & & JB JECH \\
\hline C1.302 & Verify user/error mini-screens make sense. & & JB JECH \\
\hline C1.303 & Verify mouse and key drive the selection for windows, menus, and tool bar buttons. & & JB JECH \\
\hline C1.304 & $\begin{array}{l}\text { Verify the operation of the system is interactive, providing immediate processing of } \\
\text { actions. }\end{array}$ & & JB JECH \\
\hline $\mathrm{C} 7.305$ & $\begin{array}{l}\text { Verify the system can manage itself by displaying system resources and continue to } \\
\text { be operable in the HLAN standard/ESOE environment. }\end{array}$ & & JB JEC̄H \\
\hline C1.306 & Verify the menu/tool bar buttons provide navigation to exit. & & JB JECH \\
\hline
\end{tabular}




\section{Acceptance Test Procedure \& Record}

\begin{tabular}{|c|c|c|c|c|}
\hline \multicolumn{5}{|c|}{$\begin{array}{l}\text { Test ID : } \quad \text { T1.018 } \\
\text { Test Item Description : Privilege as a Read Only User. }\end{array}$} \\
\hline ProciD & \multicolumn{4}{|l|}{ Test Procedure Description } \\
\hline P1.002 & \multicolumn{4}{|l|}{ Launch application using access privilege. } \\
\hline PI.003 & \multicolumn{4}{|l|}{ Operate the application exercising appropriate functions and features. } \\
\hline PI.006 & \multicolumn{4}{|c|}{ View information via appropriate folders or windows. } \\
\hline PI.012 & \multicolumn{4}{|c|}{$\begin{array}{l}\text { For each test case, pertorm test, record test results (Pass/Fail), date tested, and initials of testers. Enter comments in the Comment } \\
\text { Logsheet. }\end{array}$} \\
\hline Test Case ID & Test Case Description & $\mid$ Test Result|| & Date/Time & Tester \\
\hline C1.201 & $\begin{array}{l}\text { Verify the user can launch the application, log on, and ensure the application is } \\
\text { operable. }\end{array}$ & & & JB JECH \\
\hline C1.202 & Verify that access is accomplished with appropriate access privileges. & & & JB JECH \\
\hline C1.206 & Verify that use of appropriate User ID/Password enable view authorizations. & & & JB JECH \\
\hline C1.211 & $\begin{array}{l}\text { Select Folder (Pointer/References/Nameplate/Specifications/Safety) and verify it } \\
\text { was the Folder selected. }\end{array}$ & & & JB JECH \\
\hline C1.300 & $\begin{array}{l}\text { Verify that windows and menus provide navigation to appropriate Folders and their } \\
\text { associated mini-screens or drop-down lists. }\end{array}$ & & & JB JECH \\
\hline C1.301 & Verify on-line hint (yellow) boxes provide correct field definitions. & & & JB JECH \\
\hline C1.302 & Verify user/error mini-screens make sense. & & & JB JEC̈H \\
\hline C1.303 & Verify moüse and key drive the selection for windows, menus, and tool bar buttons. & & & JB JECH \\
\hline C1.304 & $\begin{array}{l}\text { Verity the operation of the system is interactive, providing immediate processing of } \\
\text { actions. }\end{array}$ & & & JB JECH \\
\hline C1.305 & $\begin{array}{l}\text { Verify the system can manage itself by displaying system resources and continue to } \\
\text { be operable in the HLAN standard/ESOE environment. }\end{array}$ & & & JB JECH \\
\hline C1.306 & Verify the menü/tool bar buttons provide navigation to exit. & & & JB JECH \\
\hline
\end{tabular}

R3.1, 89

Requirement Ref : $\quad$ SRS 3.1 (bullet 9), Gen Reqs (Acc Criteria \# 7,9,10,16,17)

Requirement Description : The MEL. Phase 1 Application shall have System Administrative features. 


\section{Master Equipment List Database Phase 1 \\ Acceptance Test Procedure \& Record}

\begin{tabular}{|c|c|c|c|c|}
\hline \multicolumn{5}{|c|}{$\begin{array}{l}\text { Test ID : } \\
\text { Test Item Description : MEL Phase } 1 \text { Application as a whole. }\end{array}$} \\
\hline Proc ID & \multicolumn{4}{|l|}{$\begin{array}{l}\text { Test Procedure Description } \\
\end{array}$} \\
\hline PI.003 & \multicolumn{4}{|l|}{ Operate the application exercising appropriate functions and features. } \\
\hline Pा.012 & \multicolumn{4}{|c|}{$\begin{array}{l}\text { For each test case, perform test, record test results (Pass/Fail), date tested, and initials of testers. Enter comments in the Comment } \\
\text { Logsheet. }\end{array}$} \\
\hline Test Case ID & Test Case Description & Test Result & Date/Time & Tester \\
\hline$\overline{\mathrm{C} 1.122}$ & Verify that System Admin. can track user changes. & & & JB JECH \\
\hline C1.123 & Verify that System Admin. can assign user access information. & & & JB JECH \\
\hline C1.207 & $\begin{array}{l}\text { Verify that use of appropriate User TD/Password enable System Admin. } \\
\text { authorizations. }\end{array}$ & & & JB JECH \\
\hline C1.208 & Verify that System Admin. can maintain definition lists. & & & JB JECH \\
\hline C..209 & $\begin{array}{l}\text { Verify that System Admin. corrective action and error messages make sense when } \\
\text { identifing a problem. }\end{array}$ & & & DEFER PER JB JECH \\
\hline C1.210 & $\begin{array}{l}\text { Verify that System Admin. corrective action messages make sense when correcting } \\
\text { a problem. }\end{array}$ & & & DEFER PER JB JECH \\
\hline $\mathrm{C} 1.213$ & $\begin{array}{l}\text { Verify appropriate information can be edited in a specific Folder by selecting the field } \\
\text { and initializing the edit with the right mouse button. }\end{array}$ & & & JB JECH \\
\hline
\end{tabular}

Requirement ID :

R3.2 (3.2.1)

Requirement Ref : $\quad$ SRS 3.2.1, Sys Admin Functions (Acc Criteria \#7, 8, 18)

Requirement Description : The MEL Phase 1 Application shall have System Administrative features 


\section{Master Equipment List Database Phase 1 \\ Acceptance Test Procedure \& Record}

\begin{tabular}{|c|c|c|c|}
\hline \multicolumn{4}{|c|}{$\begin{array}{ll}\text { Test ID : } & \text { T1.001 } \\
\text { Test Item Description : MEL Phase } 1 \text { Application as a whole. }\end{array}$} \\
\hline Proc ID & \multicolumn{3}{|l|}{ Test Procedure Description } \\
\hline PI.003 & \multicolumn{3}{|l|}{ Operate the application exercising appropriate functions and features: } \\
\hline PI.012 & \multicolumn{3}{|c|}{$\begin{array}{l}\text { For each test case, perform test, record test results (Pass/Fail), date tested, and initials of testers. Enter comments in the Comment } \\
\text { Logsheet. }\end{array}$} \\
\hline Test Case ID & Test Case Description & \begin{tabular}{|l|l|} 
Test Result & Date/Time \\
\end{tabular} & Tester \\
\hline C1.011 & Verify automatic log off occurs after idle time periods. & & DEFER PER JB JECH \\
\hline C7.122 & Verify that System Admin. can track user changes. & & JB JECH \\
\hline C1.123 & Verify that System Admin. can assign üser access information. & & JB JECH \\
\hline C1.207 & $\begin{array}{l}\text { Verify that use of appropriate User ID/Password enable System Admin. } \\
\text { authorizations. }\end{array}$ & & JB JECH \\
\hline C1.208 & Verify that System Admin. can maintain definition lists. & & JB JECH \\
\hline C1.213 & $\begin{array}{l}\text { Verify appropriate information can be edited in a specitic Folder by selecting the field } \\
\text { and initializing the edit with the right mouse button. }\end{array}$ & & JB JECH \\
\hline
\end{tabular}

Requirement ID :

R3.2 (3.2.2)

Requirement Ref

SRS 3.2.2, Data Input/Update Functions (Acc Criteria \#12,13)

Requirement Description : The user shall be able to enter new data (via popup windows), modify existing data (via folders), and import "Label Table" data into the MEL Phase $1 \mathrm{Db}$. 


\section{Master Equipment List Database \\ Phase 1 \\ Acceptance Test Procedure \& Record}

HNF-SD-WM-ATP-175, Rev. 2

\begin{tabular}{|c|c|c|c|c|}
\hline $\begin{array}{l}\text { Test ID : } \\
\text { Test Item Description : Data Input (Entry) Functions. Add additional information to an existing record/enter new records. }\end{array}$ & \multicolumn{4}{|l|}{ Test Procedure Description } \\
\hline PI.004 & \multicolumn{4}{|l|}{ Enter new information in the MEL Phase 1 Application. } \\
\hline PI.012 & \multicolumn{4}{|c|}{$\begin{array}{l}\text { For each test case, perform test, record test results (Pass/Fail), date tested, and initials of festers. Enter comments in the Comment } \\
\text { Logsheet. }\end{array}$} \\
\hline Test Case ID & Test Case Description & Test Result & Date/Time & Tester \\
\hline$\overline{c 1.204}$ & Verify that use of appropriate User ID/Password enable entry authorizations. & & & JB JECH \\
\hline C1.211 & $\begin{array}{l}\text { Select Folder (Pointer/References/Nameplate/Specifications/Safety) and verify it } \\
\text { was the Folder selected. }\end{array}$ & & & $\mathrm{JB} \mathrm{JECH}$ \\
\hline C1.212 & $\begin{array}{l}\text { Verify a new EIN can be created (using appropriate privilege) and posted and is } \\
\text { present in View mode. }\end{array}$ & & & JB JECH \\
\hline $\mathrm{C} 1.213$ & $\begin{array}{l}\text { Verify appropriate information can be edited in a specific Folder by selecting the field } \\
\text { and initializing the edit with the right mouse button. }\end{array}$ & & & JB JECH \\
\hline C1.214 & $\begin{array}{l}\text { Verify that the edited information can be viewed and verify changes are pending by } \\
\text { initializing the right mouse button and icon. }\end{array}$ & & & JB JECH \\
\hline$C 1.215$ & $\begin{array}{l}\text { Verify that pending changes and locked records are identifed by color and are } \\
\text { available to print out. }\end{array}$ & & & JB JECH \\
\hline C1.216 & $\begin{array}{l}\text { Verify that the pending changes can be posted or cancelled and the change is } \\
\text { present in View mode. }\end{array}$ & & & JB JECH \\
\hline C1.217 & Verify a new EIN can be exported in a tester-chosen format and retrieved. & & & JB JECH \\
\hline
\end{tabular}




\section{Master Equipment List Database \\ Phase 1 \\ Acceptance Test Procedure \& Record}

HNF-SD-WM-ATP-175, Rev. 2

\begin{tabular}{|c|c|c|c|c|}
\hline \multicolumn{5}{|c|}{$\begin{array}{ll}\text { Test ID : } & \text { T1.013 } \\
\text { Test Item Description : Data Edit (Update) Functions. Update information to an existing record. }\end{array}$} \\
\hline Proc ID & \multicolumn{4}{|l|}{ Test Procedure Description } \\
\hline $\mathbf{P 1 . 0 0 5}$ & \multicolumn{4}{|l|}{ Select and edit information via appropriate folders or windows. } \\
\hline P.012 & \multicolumn{4}{|c|}{$\begin{array}{l}\text { For each test case, perform test, record test results (Pass/Fail), date tested, and initials of testers. Enter comments in the Comment } \\
\text { Logsheet. }\end{array}$} \\
\hline Test Case ID & Test Case Description & Test Result & Date/Time & Tester \\
\hline$\overline{\mathrm{C} 1.203}$ & Verify that use of appropriate User ID/Password enable editing authorization. & & & JB JECH \\
\hline C1.21 & $\begin{array}{l}\text { Select Folder (Pointer/References/Nameplate/Specifications/Safety) and verify it } \\
\text { was the Folder selected. }\end{array}$ & & & JB JECH \\
\hline $\mathrm{C} 7.213$ & $\begin{array}{l}\text { Verify appropriate information can be edited in a specific Folder by selecting the field } \\
\text { and initializing the edit with the right mouse button. }\end{array}$ & & & $J B$ JECH \\
\hline C1.214 & $\begin{array}{l}\text { Verify that the edited information can be viewed and verify changes are pending by } \\
\text { initializing the right mouse button and icon. }\end{array}$ & & & JB JECH \\
\hline C7.215 & $\begin{array}{l}\text { Verify that pending changes and locked records are identifed by color and are } \\
\text { available to print out. }\end{array}$ & & & $\mathrm{JB} \mathrm{JECH}$ \\
\hline C1.216 & $\begin{array}{l}\text { Verify that the pending changes can be posted or cancelled and the change is } \\
\text { present in View mode. }\end{array}$ & & & JB JECH \\
\hline
\end{tabular}


Master Equipment List Database

HNF-SD-WM-ATP-175, Rev. 2

Phase 1

Acceptance Test Procedure \& Record

\begin{tabular}{|c|c|c|c|}
\hline Proc ID & \multicolumn{3}{|l|}{ Test Procedure Description } \\
\hline PI.010 & \multicolumn{3}{|l|}{ Manually review and inspect the appropriate documentation. } \\
\hline PI.012 & \multicolumn{3}{|c|}{$\begin{array}{l}\text { For each test case, perform test, record test results (Pass/Fall), date tested, and initials of testers. Enter comments in the Comment } \\
\text { Logsheet. }\end{array}$} \\
\hline Test Case 10 & Test Case Description & \begin{tabular}{|l|l|} 
Test Result & Date/Time \\
\end{tabular} & Tester \\
\hline$\overline{C 1.012}$ & Verify that data from specific tables can be imported via the conversion program. & & DEFER PER JB JECH \\
\hline
\end{tabular}

Requirement ID :

R3.2 (3.2.3)

Requirement Ref : $\quad$ SRS 3.2.3, Query /Retrieve Functions (Acc Criteria \#5)

Requirement Description : The MEL Phase 1 Application shall have query and retrieval functions

\begin{tabular}{|c|c|c|c|c|}
\hline \multicolumn{5}{|c|}{$\begin{array}{ll}\text { Test ID : } & \text { T1.010 } \\
\text { Test Item Description : One or more tester-chosen query selections for tester-chosen privileges. }\end{array}$} \\
\hline Proc ID & \multicolumn{4}{|l|}{ Test Procedure Description } \\
\hline PI.007 & \multicolumn{4}{|c|}{ Operate the application exercising appropriate query functions. } \\
\hline PI.012 & \multicolumn{4}{|c|}{$\begin{array}{l}\text { For each test case, perform test, record test results (Pass/Fail), date tested, and initials of testers. Enter comments in the Commen } \\
\text { Logsheet. }\end{array}$} \\
\hline Test Case ID & Test Case Description & Test Result| & \begin{tabular}{|l||} 
Date/Time \\
\end{tabular} & Tester \\
\hline$\overline{C 1.222}$ & $\begin{array}{l}\text { Build query combinations by field selection, verify use of collapse or expand, and } \\
\text { verify fieids were selected with the query answer. }\end{array}$ & & & JB JECH \\
\hline C1.223 & Verify a query setup can be saved, retrieved, modifled, and reran. & & & JB JECH \\
\hline C1.224 & Verify previously queried information can be refrieved and modified. & & & JB JECH \\
\hline C1.225 & $\begin{array}{l}\text { Verify that queried information can be exported and printed from tester-chosen } \\
\text { export application. }\end{array}$ & & & J⿹ JEC \\
\hline C1.228 & Verify queried result (EIN) information can be utilized to generate Folder reports. & & & JB JECH \\
\hline
\end{tabular}




\section{Master Equipment List Database \\ Phase 1 \\ Acceptance Test Procedure \& Record}

HNF-SD-WM-ATP-175, Rev. 2

Requirement ID

R3.2 (3.2.4)

Requirement Ref

SRS 3.2.4, Report Functions (Acc Criteria \#5)

Requirement Description : The MEL Phase 1 Application shall have reporting functions to the screen and printer.

\section{Test ID: \\ T1.019}

Test Item Description : One or more tester-chosen reporting selections for tester-chosen privileges.

\begin{tabular}{||l||l||}
\hline \multicolumn{1}{|c||}{ Proc ID } & \multicolumn{1}{c||}{ Test Procedure Description } \\
\hline \hline PI.008 & Operate the application exercising appropriate reporting/printing functions. \\
\hline P.012 & $\begin{array}{l}\text { For each test case, perorm test, record test results (Pass/Fail), date tested, and initials of testers. Enter comments in the Comment } \\
\text { Logsheet. }\end{array}$ \\
\hline
\end{tabular}

\begin{tabular}{|c|c|c|c|c|}
\hline Test Case ID & Test Case Description & Test Result & Date/Time & Tester \\
\hline$\overline{C 1.118}$ & Prepare tester-chosen Folder report and verify functions can be performed. & & & JB JECH \\
\hline C1.119 & Display preview information report and verify a view on the screen. & & & JB JECH \\
\hline C1.120 & Display preview information report and verify the report can print. & & & $\mathrm{JB} \mathrm{JECH}$ \\
\hline C1.121 & Display preview information report and copy to file; verify file was copied. & & & $\mathrm{JB} \mathrm{JECH}$ \\
\hline C1.218 & $\begin{array}{l}\text { Prepare tester-chosen report (i.e., revise or customize) using System Admin. } \\
\text { functions and verify function(s) can be performed. }\end{array}$ & & & $\overline{\mathrm{JB}} \mathrm{JECH}$ \\
\hline C1.219 & Display preview information report and verify a view on the screen. & & & JB JECH \\
\hline$C 1.220$ & Display preview information report and verify the report can print. & & & JB JECH \\
\hline C1.221 & Display preview information report and copy to file; verify file was copied. & & & JB JECH \\
\hline
\end{tabular}

Requirement ID :

R3.2 (3.2.5)

Requirement Ref

SRS 3.2.5, Multi-Use Functions (Acc Criteria \#4)

Requirement Description : The MEL Phase 1 Application shall support a multiple user environment. 


\section{Acceptance Test Procedure \& Record}

\begin{tabular}{|l|l|l|l|}
\hline Test ID: & T1.022 \\
Test Item Description : MEL Phase 1 Application as a whole (supports Multiple Users). \\
\hline Pr.003 & Operate the application exercising appropriate functions and features. \\
\hline PI.012 & For each test case, perorm test, record test results (Pass/Fail), date tested, and initials of testers. Enter comments in the Comment \\
\hline Logsheet.
\end{tabular}

Requirement ID :

R3.2 (3.2.6)

Requirement Ref : $\quad$ SRS 3.2.6, BackUp Functions (Acc Criteria 14)

Requirement Description : The MEL Phase 1 Application shall have menu options for backup support.

\begin{tabular}{|l|l|l|l|l|}
\hline Test ID : & T1.004 \\
Test Item Description : MEL Phase 1 Application as a whole (supports Backups). \\
\hline PI.011
\end{tabular}




\section{Master Equipment List Database \\ Phase 1 \\ Acceptance Test Procedure \& Record}

Requirement ID :

Requirement Ref

R3.3 (3.3.1)

Requirement Description : The user shall be able to interface with the MEL Phase 1 Application through use of menu/mouse driven selections, on-line help, and pop-up windows.

\section{Test ID: $\quad$ T1.002}

Test Item Description : MEL Phase 1 Application as a whole (supports User-Friendly Interface).

\begin{tabular}{||l||l||}
\hline \multicolumn{1}{||c|}{ Proc ID } & \multicolumn{1}{|c||}{ Test Procedure Description } \\
\hline \hline PI.003 & $\begin{array}{l}\text { Operate the application exercising appropriate functions and features. } \\
\text { PI.012 }\end{array}$ \\
\hline
\end{tabular}

\begin{tabular}{|c|c|c|c|c|}
\hline Test Case ID & Test Case Description & 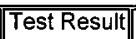 & Date/Time & Tester \\
\hline C1.300 & $\begin{array}{l}\text { Verify that windows and menus provide navigation to appropriate Folders and their } \\
\text { associated mini-screens or drop-down lists. }\end{array}$ & & & JB JECH \\
\hline C.301 & Verify on-line hint (yellow) boxes provide correct field definitions. & & & $\mathrm{JB}$ JECH \\
\hline$C 1.302$ & Verify user/error mini-screens make sense. & & & JB JECH \\
\hline C1.303 & Verify mouse and key drive the selection for windows, menus, and tool bar buttons. & & & JB JECH \\
\hline C1.304 & $\begin{array}{l}\text { Verify the operation of the system is interactive, providing immediate processing of } \\
\text { actions. }\end{array}$ & & & JB JECH \\
\hline C1.306 & Verify the menu/toolbar buttons provide navigation to exit. & & & JB JECH \\
\hline C1.307 & Verify Help buttons provide on-line assistance. & & & DEFER PER JB JECH \\
\hline
\end{tabular}

\section{Requirement ID :}

Requirement Ref :

Requirement Description : The MEL. Phase 1 Application shall operate on the minimium hardware requirements of a IBM pc $486 / 33,8 \mathrm{Mb}$ main processor memory and 30 meg free hard disk space.

R3.3 (3.3.2)

SRS 3.3.2, Hardware Interfaces 
Master Equipment List Database

Phase 1

\section{Acceptance Test Procedure \& Record}

Test Item Description : MEL Phase 1 Application as a whole (supports Minimum Hardware Requirements).

\begin{tabular}{||l|l||}
\hline \multicolumn{1}{|c|}{ Proc ID } & \multicolumn{1}{|c|}{ Test Procedure Description } \\
\hline PI.009 & Use a minimum system as specified in the requirements. \\
PI.012 & $\begin{array}{l}\text { For each test case, perform test, record test results (Pass/Fail), date tested, and initials of testers. Enter comments in the Comment } \\
\text { Logsheet. }\end{array}$ \\
\hline
\end{tabular}

\begin{tabular}{|c|c|c|c|c|}
\hline Test Case ID & Test Case Description & Test Result & Date/Time & Tester \\
\hline C1.004 & Verify with the developer that by design, test item meets requirements. & & & $\overline{J B \mathrm{JECH}}$ \\
\hline C1.005 & $\begin{array}{l}\text { Verify with the beta testers that the application can be installed and is compatible } \\
\text { and operable using minimum hardware requirements. }\end{array}$ & & & JB JECH \\
\hline
\end{tabular}

Requirement ID :

Requirement Ref

Requirement Description : The MEL Phase 1 Application shall be accessible via the HLAN. Installation of

the system shall setup and be compatible with the user's computer environment.

\begin{tabular}{|c|c|c|c|}
\hline Proc ID & \multicolumn{3}{|l|}{ Test Procedure Description } \\
\hline Pl.001 & \multicolumn{3}{|l|}{ Operate system in the HLAN standard/ESOE environment. } \\
\hline Pा.012 & \multicolumn{3}{|c|}{$\begin{array}{l}\text { For each test case, perform test, record test results (Pass/Fail), date tested, and initials of testers. Enter comments in the Comment } \\
\text { Logsheet. }\end{array}$} \\
\hline Test Case ID & Test Case Description & \begin{tabular}{|l|l|} 
Test Result & Date/Time \\
\end{tabular} & Tester \\
\hline$\overline{c 1.006}$ & $\begin{array}{l}\text { Verify the application can install and is compatible with the HLAN standard/ESOE } \\
\text { computer environment. }\end{array}$ & & JB JECH \\
\hline C7.201 & $\begin{array}{l}\text { Verify the user can launch the application, log on, and ensure the application is } \\
\text { operable. }\end{array}$ & & JB JECH \\
\hline
\end{tabular}




\section{Master Equipment List Database \\ Phase 1 \\ Acceptance Test Procedure \& Record}

HNF-SD-WM-ATP-175, Rev 2

Requirement ID :

R3.4

Requirement Ref :

SRS 3.4, Performance Requirements (Acc Criteria \#4)

Requirement Description : The MEL Phase 1 Application shall meet reponse times of $<2$ secs for input/edits, $<30$ secs for data queries $<1 \mathrm{~min} / \mathrm{page}$ for re- porting and $<1 \mathrm{~min}$ for startup. Times for multi-use is 6-10 users (data entry \& editing) and 25-50 users (query \& reports)

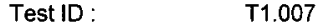

Test Item Description : MEL Phase 1 Application as a whole (supports Adequate Response Times).

\begin{tabular}{|c|c|}
\hline Proc ID & Test Procedure Description \\
\hline Pl.003 & Operate the application exercising appropriate functions and features. \\
\hline P.012 & $\begin{array}{l}\text { For each fest case, perform test, record test results (Pass/Fail), date tested, and initials of testers. Enter comments in the Comment } \\
\text { Logsheet. }\end{array}$ \\
\hline
\end{tabular}

\begin{tabular}{|c|c|c|c|}
\hline Test Case ID & Test Case Description & Test Result: Date/Time & Tester \\
\hline C1.007 & Ensure test cases are performed and accepted. & & JB JECH \\
\hline $\mathrm{C1.304}$ & $\begin{array}{l}\text { Verify the operation of the system is interactive, providing immediate processing of } \\
\text { actions. }\end{array}$ & & $\mathrm{JB}$ JECH \\
\hline
\end{tabular}

Requirement ID R3.5 (3.5.1)

Requirement Ref

SRS 3.5.1, Standards Compliance (Acc Criteria \# 19, 20)

Requirement Description: The MEL Phase 1 Application shall have the appropriate documentation that meets quality affecting software requirements. 


\section{Master Equipment List Database}

Phase 1

Acceptance Test Procedure \& Record

Test ID :
Test Item Description : MEL. Phase 1 Application as a whole (supports Standard Compliance).

\begin{tabular}{||l|l||}
\hline \multicolumn{1}{|c|}{ Proc ID } & \multicolumn{1}{|c|}{ Test Procedure Description } \\
\hline PI.010 & $\begin{array}{l}\text { Manually review and inspect the appropriate documentation. } \\
\text { PI.012 }\end{array}$ \\
\hline & \begin{tabular}{l} 
Lor each test case, perform test, record test results (Pass/Fail), date tested, and initials of testers. Enter comments in the Comment \\
\hline
\end{tabular} \\
\hline
\end{tabular}

Test Case ID

Test Case Description

\begin{tabular}{|l|l|l|}
\hline Test Result & Date/Time \\
\hline & \\
\hline
\end{tabular}

JB JECH

\begin{tabular}{l|l}
\hline C1.007 & Ensure test cases are performed and accepted
\end{tabular}

\begin{tabular}{|l|l} 
C1.010 & Manually verify system Quality Assurance documentation are written and approved.
\end{tabular}

DEFER PER JB JECH

Requirement ID :

R3.6 (3.6.4)

Requirement Ref :

SRS 3.6.4, Reliability/ Recovery (Acc Criteria \# 9,10,16,17)

Requirement Description : The MEL Phase 1 Application shall be reliable during normal operation

interaction. Failure to restart or to recover data during a system failure is not

critical. For recovery, an activity log and system admin features and functions

shall be available. 


\section{Acceptance Test Procedure \& Record}

\begin{tabular}{|c|c|c|c|c|}
\hline Proc ID & \multicolumn{4}{|l|}{ Test Procedure Description } \\
\hline P1.003 & \multicolumn{4}{|l|}{ Operate the application exercising appropriate functions and features. } \\
\hline PI.012 & \multicolumn{4}{|c|}{$\begin{array}{l}\text { For each test case, perform test, record test results (Pass/Fall), date tested, and initials of testers. Enter comments in the Comment } \\
\text { Logsheet. }\end{array}$} \\
\hline Test Case ID & \begin{tabular}{|l|l} 
& Test Case Description \\
\end{tabular} & Test Result & Date/Time & Tester \\
\hline$\overline{\mathrm{C} 1.002}$ & $\begin{array}{l}\text { Verify that the HLAN Administrator is providing backup support per System Admin. } \\
\text { instructions. }\end{array}$ & & & JB JECH \\
\hline C1.003 & Verify that the menu options provide backup support. & & & JB JECH \\
\hline$C 1.006$ & $\begin{array}{l}\text { Verify the application can install and is compatible with the HLAN standard/ESOE } \\
\text { computer environment. }\end{array}$ & & & JB JECH \\
\hline C1.011 & Verify automatic log off occurs after idle time periods. & & & DEFER PER JB JECH \\
\hline C1.122 & Verify that System Admin. can track user changes. & & & JB JECH \\
\hline C1.123 & Verify that System Admin. can assign user access information. & & & JB JECH \\
\hline C7.208 & Verify that System Admin. can maintain definition lists. & & & JB JECH \\
\hline$C 1.209$ & $\begin{array}{l}\text { Verity that System Admin. corrective action and error messages make sense when } \\
\text { identifing a problem. }\end{array}$ & & & DEFER PER JB JECH \\
\hline$C 1.210$ & $\begin{array}{l}\text { Verify that System Admin. corrective action messages make sense when correcting } \\
\text { a problem. }\end{array}$ & & & DEFER PER JB JECH \\
\hline C1.304 & $\begin{array}{l}\text { Verify the operation of the system is interactive, providing immediate processing of } \\
\text { actions. }\end{array}$ & & & JB JECH \\
\hline
\end{tabular}

Requirement ID :

R3.6 (3.6.7)

Requirement Ref :

SRS 3.6.7, Training (Acc Criteria \#1)

Requirement Description : The MEL Phase 1 Application shal! have on-line help functions to minimize the training involved for users. 


\section{Acceptance Test Procedure \& Record}

\begin{tabular}{|c|c|c|c|c|}
\hline \multicolumn{5}{|c|}{$\begin{array}{l}\text { Test ID : } \quad \text { T1.021 } \\
\text { Test Item Description : MEL Phase 1 Application as a whole (supports On-Line Help). }\end{array}$} \\
\hline Proc ID & \multicolumn{4}{|l|}{ Test Procedure Description } \\
\hline$\overline{\mathrm{Pl}} .003$ & \multicolumn{4}{|c|}{ Operate the application exercising appropriate functions and features. } \\
\hline PI.012 & \multicolumn{4}{|c|}{$\begin{array}{l}\text { For each test case, perform test, record test results (Pass/Fall), date tested, and initials of testers. Enter comments in the Comment } \\
\text { Logsheet. }\end{array}$} \\
\hline Test Case ID & Test Case Description & Test Result & Date/Time & Tester \\
\hline C1.300 & $\begin{array}{l}\text { Verify that windows and menus provide navigation to appropriate Folders and their } \\
\text { associated mini-screens or drop-down lists. }\end{array}$ & & & JB JECH \\
\hline C1.301 & Verity on-line hint (yellow) boxes provide correct field definitions. & & & JB JECH \\
\hline C1.302 & Verify user/error mini-screens make sense. & & & JB JECH \\
\hline C1.303 & Verity mouse and key drive the selection for windows, menus, and tool bar buttons. & & & JB JECH \\
\hline C1.306 & Verify the menu/tool bar buttons provide navigation to exit. & & & JB JECH \\
\hline C1.307 & Verify Help buttons provide on-line assistance. & & & DEFER PER JB JECH \\
\hline
\end{tabular}


APPENDIX B ACCEPTANCE TEST PROCEDURE RECORD (MULTI-USER) 


\section{MASTER EQUIPMENT LIST DATABASE \\ PHASE 1, VERSION 1.33 \\ MULTI-USER \\ ACCEPTANCE TEST PROCEDURE \& RECORD}

\section{AN ATTACHMENT TO: MASTER EQUIPMENT LIST DATABASE \\ PHASE 1, VERSION 1.32 \\ ACCEPTANCE TEST PROCEDURE \& RECORD \\ WHC-SD-WM-ATP-175, REV. 1}

PERFORMED BY:

FACILITY CONFIGURATION MANAGEMENT INTEGRATION

Approved for Use: $\underline{\text { J. B. Jech }}$ Date:

Approved for Use: M. W. Thornton Date: 


\begin{tabular}{|c|c|c|c|c|c|c|c|c|c|c|c|c|}
\hline \multicolumn{13}{|c|}{$\begin{array}{l}\text { MASTER EQUIPMENT LIST - MULTI-USER ACCEPTANCE TEST PROCEDURE } \\
\text { TEST CASE/TIME ASSIGNMENTS } \\
\text { December 9, 1996 (9:00 am - 12:00 pm) }\end{array}$} \\
\hline \multicolumn{13}{|c|}{ Time } \\
\hline Name & $\begin{array}{l}8: 00 \\
8: 15\end{array}$ & $\begin{array}{l}8: 15 \\
8: 30\end{array}$ & $\begin{array}{l}8: 30 \\
8: 45\end{array}$ & $\begin{array}{l}\text { 8:45 } \\
9: 00\end{array}$ & $\begin{array}{l}9: 00 \\
9: 15\end{array}$ & $\begin{array}{l}9: 15 \\
9: 30\end{array}$ & $\begin{array}{l}9: 30 \\
9: 45\end{array}$ & $\begin{array}{l}9: 45 \\
10: 00\end{array}$ & $\begin{array}{l}10: 00 \\
10: 15\end{array}$ & $\begin{array}{l}10: 15 \\
10: 30\end{array}$ & $\begin{array}{l}10: 30 \\
10: 45\end{array}$ & $\begin{array}{l}10: 45 \\
11: 00\end{array}$ \\
\hline $\begin{array}{l}\text { Baker- } \\
\text { RO }\end{array}$ & 1a-d & $1 \mathrm{a}-\mathrm{d}$ & $1 \mathrm{~h}-1 \mathrm{j}$ & $1 \mathrm{~h}-1 \mathrm{j}$ & BREAK & 2 & 2 & 2 & 2 & BREAK & 7 & 7 \\
\hline Douka-LA & $1 a-1 d$ & $1 \mathrm{e}$ & $1 \mathrm{f}$ & $\lg$ & BREAK & $3 a-3 f$ & $\begin{array}{l}3 \mathrm{a}-\mathrm{c} \\
3 \mathrm{~g}-\mathrm{i}\end{array}$ & 4 & 5 & 5 & $\begin{array}{l}8 \mathrm{a}, \mathrm{f}, \mathrm{h}, \\
\mathrm{i}, \mathrm{j}, \mathrm{k}\end{array}$ & $\begin{array}{l}8 a, f, h, \\
i, j, k\end{array}$ \\
\hline $\begin{array}{l}\text { Duerr- } \\
\mathrm{P} / \mathrm{R} / \mathrm{S}\end{array}$ & $3 a-3 f$ & $\begin{array}{l}3 \mathrm{a}-\mathrm{c} \\
3 \mathrm{~g}-\mathrm{i}\end{array}$ & 4 & 4 & BREAK & $1 \mathrm{a}-\mathrm{d}$ & $1 \mathrm{a}-\mathrm{d}$ & $1 \mathrm{~h}-\mathrm{j}$ & $1 h-j$ & 2 & 2 & 2 \\
\hline $\begin{array}{l}\text { Fordham- } \\
\text { P/NP/SP }\end{array}$ & $3 a-f$ & $\begin{array}{l}3 \mathrm{a}-\mathrm{c} \\
3 \mathrm{~g}-\mathrm{I}\end{array}$ & 4 & 4 & BREAK & $1 a-d$ & la-d & $1 \mathrm{~h}-\mathrm{j}$ & $1 h-j$ & 2 & 2 & 2 \\
\hline $\begin{array}{l}\text { Geiss - } \\
\text { P/NP }\end{array}$ & 7 & 7 & 2 & 2 & 2 & BREAK & la-d & la-d & $1 \mathrm{~h}-\mathrm{j}$ & $1 h-j$ & $3 a-f$ & $3 \mathrm{a}-\mathrm{f}$ \\
\hline Jech-SA & 3 & 3 & 3 & 4 & 4 & BREAK & la-d & 1a-d & $1 \mathrm{e}-\mathrm{g}$ & le-g & $\begin{array}{l}8 \mathrm{a}, \mathrm{f}, \mathrm{h}, \\
\mathrm{i}, \mathrm{j}, \mathrm{k}\end{array}$ & $\begin{array}{l}8 \mathrm{a}, \mathrm{f}, \mathrm{h}, \\
\mathrm{i}, \mathrm{j}, \mathrm{k}\end{array}$ \\
\hline $\begin{array}{l}\text { Weddle - } \\
R / S\end{array}$ & $1 a-d$ & $1 a-d$ & $1 h-j$ & $1 \mathrm{~h}-\mathrm{j}$ & BREAK & 2 & 2 & $3 a-3 f$ & $\begin{array}{l}3 \mathrm{a}-\mathrm{c} \\
3 \mathrm{~g}-\mathrm{i}\end{array}$ & 4 & 4 & 7a, 7e-f \\
\hline $\begin{array}{l}\text { White- } \\
\text { RO }\end{array}$ & $1 \mathrm{a}-\mathrm{d}$ & $1 a-d$ & $1 h-j$ & $1 \mathrm{~h}-\mathrm{j}$ & BREAK & 7 & 7 & 2 & 2 & BREAK & $8 \mathrm{c}, \mathrm{d}, \mathrm{e}$ & $8 \mathrm{c}, \mathrm{d}, \mathrm{e}$ \\
\hline $\begin{array}{l}\text { Wyatt- } \\
\text { NP/SP }\end{array}$ & $1 a-d$ & $1 \mathrm{a}-\mathrm{d}$ & $1 h-j$ & $1 \mathrm{~h}-\mathrm{j}$ & BREAK & 2 & 2 & $3 a-f$ & $\begin{array}{l}3 a-c \\
3 g-i\end{array}$ & 4 & $8 \mathrm{c}, \mathrm{d}, \mathrm{e}$ & $8 \mathrm{c}, \mathrm{d}, \mathrm{e}$ \\
\hline \multicolumn{13}{|c|}{$\begin{array}{l}\text { Access Control: } \\
\text {-Edit Data by Folder: Pointer (P), Safety (S), Reference (R), NamePlate (NP), Specifications (SP). } \\
\text {-Admin Levels: Label Administrator (LA) is accessible to EIN Related Fields, System Administrator (SA) is accessible to All Functions. } \\
\text {-Read Only (RO) is accessible to view information; no editing. }\end{array}$} \\
\hline
\end{tabular}




\begin{tabular}{|c|c|}
\hline \multicolumn{2}{|r|}{$\begin{array}{l}\text { MASTER EQUIPMENT LIST - MULTI-USER ACCEPTANCE TEST PROCEDURE } \\
\text { TEST CASE/TIME ASSIGNMENTS } \\
\text { December 9, 1996 (8:00 am - 12:00 pm) }\end{array}$} \\
\hline Test Case & Description \\
\hline $\begin{array}{l}\text { 1) Perform } \\
\text { Queries }\end{array}$ & $\begin{array}{l}\text { a) Build a query for an EIN and four fields. For the four fields' value, select All Values. } \\
\text { b) View results and select one of the fields' values to narrow the results. Define the value of the field in the query } \\
\text { setup and execute. } \\
\text { c) View results and verify that the defined value is part of the result. Continue to define fields to narrow down a } \\
\text { data set. Verify that the functions Collapse and Expand work. } \\
\text { d) Write down the query built as parameters are defined, to assist in verifying the results. } \\
\text { e) Export the query results to a .db file. Verify it can be retrieved in Paradox. } \\
\text { f) Export the query results to a .txt file. Verify it can be retrieved in WordPerfect. } \\
\text { g) Save the query results to Reports. Print out the appropriate Folder reports (s) using the Query Results EIN List. } \\
\text { h) Save the query to (Save Query) in order to retrieve it later. Verify it can be retrieved. } \\
\text { i) Retrieve the saved query, build upon it, execute it, and resave it (Save Query As) with a different filename. } \\
\text { j) Verify there are two saved query files. }\end{array}$ \\
\hline 2) Reporting & $\begin{array}{l}\text { a) Without building a query, select three Folder reports to print. } \\
\text { b) Select } 5 \text { EINs to print for each of the Folder reports. } \\
\text { c) Print two Folder reports to the printer and print one to the screen. } \\
\text { d) Verify that the } 5 \text { EINs printed out in the appropriate Folder reports. } \\
\text { e) In View, manually verify for two Folder reports (for each data field) that the data printed out exactly what is } \\
\text { presented on the screen. } \\
\text { f) Verify that the Folder report can be exported to a .txt file and retrieved. }\end{array}$ \\
\hline
\end{tabular}




\begin{tabular}{|l|l|}
\hline 3) Edit Session & $\begin{array}{l}\text { a) Perform a Quick Search to locate an EIN (system) that needs editing. } \\
\text { b) Begin an edit session and verify all information is required to proceed. Note the "Reminder. } \\
\text { c) Verify that an edit session cannot begin unless the right mouse button is initiated. } \\
\text { Single Record Edits: } \\
\text { d) Verify that changes can be made for a single record, but leave one field unchanged (will still be locked). } \\
\text { e) Do not release the session. Verify while you're still in Edit, that the Padlock icon enables the Locks and } \\
\text { Changes Pending form and that the record can be re-edited. Verify the changes are present. Click Folders icon. } \\
\text { f) Verify that from the Edit Menu, "View Changes", enables the Changes Pending form and that the record can be } \\
\text { re-edited again. Verify on the Folder that the fields are blue. Exit from Edit mode. } \\
\text { New Record Edits: } \\
\text { g) Verify that changes can be made for a multi-record (i.e., procedures field). Enter } 2 \text { new records (procedure } \\
\text { numbers). Verify on the Folder that the fields are blue (temporarily - until record moves to Changes Pending). } \\
\text { h) Verify on } 2 \text { more new records that immediately after inserting that the change can be posted individually. } \\
\text { i) Verify on the } 2 \text { new records that after entering it AND moving off the cell that it cannot be posted. Verify that } \\
\text { from the Edit Menu, "View New Records", enables the New Record Pending form. Verify that in this form that } \\
\text { the new record cannot be re-edited. Exit from Edit mode. }\end{array}$ \\
\hline 4) Release Session & $\begin{array}{l}\text { a) Click on the Padlock icon and verify that it enables the Locks and Changes Pending form. } \\
\text { b) Verify that pending changes and locks can be viewed by Session. } \\
\text { c) By User, verify that the pending changes and locks are correct values and post. Click on Folders icon. } \\
\text { d) By Session, verify that the pending changes and locks are correct values and post. Click on Folders icon. } \\
\text { e) In View, verify that once posted, each of the values are no longer colored blue. } \\
\text { f) Verify that in Change Log that the changes are present. }\end{array}$ \\
\hline
\end{tabular}




\begin{tabular}{|c|c|}
\hline 5) Label Admin. & $\begin{array}{l}\text { Creating a new EIN } \\
\text { a) Begin an edit session and verify all information is required to proceed. } \\
\text { b) Verify that a new EIN can be created and exported to a .db file. Verify it can be retrieved in Paradox. } \\
\text { c) Verify that the new EIN can be posted to the Locks and Changes Pending form. From there release the session } \\
\text { by posing. } \\
\text { d) Verify that the EIN can be located using Quick Search and begin an edit session to add more information to the } \\
\text { Folders. } \\
\text { e) Verify that the 'new record' is enabled from the Edit menu. Verify that information can be inserted in all the } \\
\text { Folders, all fields. Add two for each of the multi-record fields (i.e., procedures, drawing nos.). } \\
\text { f) Post the pending changes and verify that the information is present in View. } \\
\text { Delete } \\
\text { g) Begin an edit session and verify all information is required to proceed. } \\
\text { h) Mark one individual record in a Folder for deletion. Delete the record via the Edit Menu. } \\
\text { i) Mark an entire EIN record for deletion and delete via the Edit Menu in the Equipment Identification area. }\end{array}$ \\
\hline 6) System Admin. & $\begin{array}{l}\text { a) Verify edit sessions are recorded in the Change Control Activity form. } \\
\text { b) Verify the fields, Time and User are correct. } \\
\text { c) Edit the Definitions List. Verify that the drop-down lists are updated. } \\
\text { d) Perform refresh test with a new EIN that has been posted by the Label Admin. } \\
\text { e) Mark an EIN record and multi-record for deletion. Post individually. Delete the full EIN from the Edit menu } \\
\text { and verify that it is no longer present. } \\
\text { f) Change the access level of one User from an editing privilege to a Read Only (see } 8 \mathrm{k} \text { ). }\end{array}$ \\
\hline 7) Read Only & $\begin{array}{l}\text { a) Perform a Quick Search to locate a set of EINs. } \\
\text { b) View all Folders. } \\
\text { c) Verify that the buttons and icons on the toolbar are functional. } \\
\text { d) Verify that editing privileges are not available. } \\
\text { e) Identify specific fields and their values for EINs that could be used in a Find. } \\
\text { f) Verify that performing a Find and Find Next functions work. }\end{array}$ \\
\hline
\end{tabular}




\begin{tabular}{|c|c|}
\hline $\begin{array}{l}\text { 8) Conflicting } \\
\text { Test Cases }\end{array}$ & $\begin{array}{l}\text { a) } 2 \text { Testers - Mark a full EIN locked (do not post) and verify that it can be queried. } \\
\text { b) } 2 \text { Testers - Perform a Find on a specific field and at the same time set that field up as part of a query and } \\
\text { execute. } \\
\text { c) } 2 \text { Testers - Perform a Quick Search on the same EIN. } \\
\text { d) } 2 \text { Testers - Perform the same query set up and execute it at the same time. } \\
\text { e) } 2 \text { Testers - View the Change Log while another person posts an edit. Verify it updates after a Refresh. } \\
\text { f) } 2 \text { Testers - Have both users enable an edit session and attempt to edit the same EIN, using different Folders, and } \\
\text { then the same Folder, and then the same Field. } \\
\text { g) SA/LA - Perform a Refresh test of a newly created and posted EIN. } \\
\text { h) SA/LA - Perform a Refresh test of a newly created and posted record in an EIN. } \\
\text { i) SA/LA - Perform a Refresh test of a newly deleted EIN. } \\
\text { j) SA/Tester - Change a user's privilege in the middle of an edit session to Read Only. Verify that when the User } \\
\text { exits MEL and logs back on that the new privilege is present. }\end{array}$ \\
\hline $\begin{array}{l}\mathbf{N} \\
0 \\
0\end{array}$ & $\begin{array}{l}\text { if there is a time that the system is not responding to an mouse click, hit the ESC button. } \\
\text { \#8, please write out the results. } \\
\text { roblem occurrence, complete the Problem Report form. Write out each step that made yo }\end{array}$ \\
\hline
\end{tabular}

